\title{
Tests op betrouwbaarheid en validiteit van kwaliteitsscores voor de resultaten van onderwijs
}

Citation for published version (APA):

Allen, J. P. (2006). Tests op betrouwbaarheid en validiteit van kwaliteitsscores voor de resultaten van onderwijs. Researchcentrum voor Onderwijs en Arbeidsmarkt, Faculteit der Economische

Wetenschappen. ROA Working Papers No. 004 https://doi.org/10.26481/umarow.2006004

Document status and date:

Published: 01/01/2006

DOI:

10.26481/umarow.2006004

Document Version:

Publisher's PDF, also known as Version of record

\section{Please check the document version of this publication:}

- A submitted manuscript is the version of the article upon submission and before peer-review. There can be important differences between the submitted version and the official published version of record.

People interested in the research are advised to contact the author for the final version of the publication, or visit the DOI to the publisher's website.

- The final author version and the galley proof are versions of the publication after peer review.

- The final published version features the final layout of the paper including the volume, issue and page numbers.

Link to publication

\footnotetext{
General rights rights.

- You may freely distribute the URL identifying the publication in the public portal. please follow below link for the End User Agreement:

www.umlib.nl/taverne-license

Take down policy

If you believe that this document breaches copyright please contact us at:

repository@maastrichtuniversity.nl

providing details and we will investigate your claim.
}

Copyright and moral rights for the publications made accessible in the public portal are retained by the authors and/or other copyright owners and it is a condition of accessing publications that users recognise and abide by the legal requirements associated with these

- Users may download and print one copy of any publication from the public portal for the purpose of private study or research.

- You may not further distribute the material or use it for any profit-making activity or commercial gain

If the publication is distributed under the terms of Article $25 \mathrm{fa}$ of the Dutch Copyright Act, indicated by the "Taverne" license above, 


\section{Tests op betrouwbaarheid en validiteit van kwaliteitsscores voor de resultaten van onderwijs}

ROA-W-2006/4

Jim Allen

Researchcentrum voor Onderwijs en Arbeidsmarkt

Faculteit der Economische Wetenschappen en Bedrijfskunde Universiteit Maastricht

Maastricht, juni 2006 
ISBN-10: 90-5321-440-2

ISBN-13: 978-90-5321-440-4

Sec06.050 
Inhoud

Pagina

1 Inleiding 1

2 Test op gevoeligheid voor aantal cases per opleiding 2

3 Validiteitstesten 6

$4 \quad$ Beoordeling van verschillen $\quad 18$

$\begin{array}{ll}\text { Literatuur } & 21\end{array}$

Bijlage: Berekening kwaliteitsindicatoren 22 



\section{Inleiding}

Bij het beoordelen van de resultaten van het onderwijs wordt een drietal functies onderscheiden: de kwalificatiefunctie, de selectiefunctie en de allocatiefunctie (Peschar \& Wesselingh, 2001). Bij de kwalificatiefunctie van het onderwijs gaat het om de vraag of het onderwijs de studenten heeft uitgerust met die competenties die relevant zijn voor de doorstroming naar de arbeidsmarkt. De selectiefunctie betreft het beoordelen van studenten op de aanwezige competenties en het op grond hiervan certificeren naar eindniveau. Bij de allocatiefunctie gaat het om de ondersteuning bij de transitie van opleiding naar werk en de aansluiting van de opleiding op het gevonden werk. Voor alle drie functies wordt naar de doeltreffendheid gekeken. Alleen voor de allocatiefunctie wordt ook naar de doelmatigheid gekeken: het externe rendement. Voor een uitgebreide beschrijving van het conceptuele kader, zie Allen et al (2006) of Allen, Ramaekers en van der Velden (2005).

Voor de doeltreffendheid van de kwalificatiefunctie zijn vijf indicatoren ontwikkeld, die betrekking hebben op het competentieniveau van afgestudeerden, de mate waarin de opleiding een goede basis bood om op de arbeidsmarkt te starten respectievelijk om verder te leren, en het oordeel over de breedte en diepgang van de opleiding. Voor de selectiefunctie zijn vier indicatoren ontwikkeld, voor de zwaarte van de selectie, de tevredenheid met de opleidingskeuze, de moeilijkheidsgraad van de opleiding en de wijze van toetsen en beoordelen. De vijf indicatoren van de allocatiefunctie hebben betrekking op de mate van tevredenheid met de beroepsvoorlichting, het vereiste niveau van huidige functie, het oordeel over de aansluiting tussen de opleiding en de huidige functie, de mate waarin de kennis en vaardigheden in de huidige functie worden benut, en de mate van tevredenheid met de huidige baan. Voor het externe rendement zijn drie indicatoren ontwikkeld, namelijk de kans op werk, de carrièremogelijkheden en het uurloon. Naast deze indicatoren voor de resultaten van het onderwijs zijn een aantal indicatoren opgenomen ter evaluatie van het programma (opbouw studieprogramma, keuzemogelijkheden en samenhang tussen vakken), de inzet van personeel (de kwaliteit van docenten en studiebegeleiding) en voorzieningen (huisvesting en overige materiele voorzieningen). Alle gebruikte indicatoren zijn gebaseerd op het percentage afgestudeerden dat een bepaalde norm haalt. Voor een gedetailleerde specificatie van de wijze waarop de verschillende indicatoren van de kwalificatiefunctie zijn geoperationaliseerd en hoe deze zijn getransformeerd naar een rapportcijfer wordt verwezen naar de bijlage.

Dit indicatorenstelsel dient een belangrijke input te vormen bij de accreditatie van opleidingen in het hoger onderwijs, in het bijzonder voor het aspect 'resultaten van het onderwijs'. De bruikbaarheid van dit indicatorenstelsel staat of valt met de validiteit en betrouwbaarheid van de kwaliteitsscores. Het zal niet goed mogelijk zijn om robuuste conclusies te trekken over de kwaliteit van het onderwijs wanneer de betekenis van deze scores ter discussie staat. ${ }^{1}$

1. Omdat verschillende opleidingen verschillende doelstellingen kunnen nastreven, kunnen de implicaties van bepaalde uitkomsten per opleiding verschillen. Dit neemt niet weg dat de fundamentele betekenis van de cijfers uniform dient te zijn. 
In dit document worden de resultaten van een aantal tests op de betrouwbaarheid en validiteit van de gebruikte indicatoren gepresenteerd. In de volgende paragraaf wordt nagegaan in hoeverre de resultaten gevoelig zijn voor het aantal cases per opleiding. Aan de hand hiervan wordt een ondergrens bepaald voor het weergeven van cijfers. In paragraaf 3 komt de validiteit aan bod. In paragraaf 4 tenslotte wordt nagegaan aan de hand van welke criteria betekenisvolle verschillen tussen instellingen kunnen worden vastgesteld.

\section{Test op gevoeligheid voor aantal cases per opleiding}

Kleine eenheden

Het streven is om kwaliteitsscores te leveren per opleiding per instelling per jaar. Op dit aggregatieniveau is echter - op een aantal uitzonderingen na - het aantal waarnemingen niet erg groot. Om een idee te geven, tabel 2.1 geeft de verdeling van opleidingsinstellingscombinaties voor het HBO en WO in 2005.

Tabel 2.1

Grootte van opleidings-instellingscombinaties, HBO en WO 2005

Grootte van eenheid

Aantal Percentage

- $\quad<10$

- $10-19$

- $20-49$

- $50-99$

- $>=100$

Tabel 2.1 maakt duidelijk dat verreweg de meeste eenheden waarover wordt gerapporteerd inderdaad erg klein zijn. Bijna tweederde bevat minder dan 20 waarnemingen (waarvan de meeste eenheden zelfs kleiner zijn dan 10), en slechts een kleine $3 \%$ bevat meer dan 100 waarnemingen. Dit levert potentieel een probleem op voor wat de robuustheid van de cijfers betreft. Naarmate de cijfers op minder cases zijn gebaseerd, gaat toeval een grotere rol spelen.

\section{Gevoeligheidsanalyse}

Om na te gaan hoe gevoelig de cijfers zijn voor het aantal cases per rapportage-eenheid, is een databestand aangemaakt met uitsluitend relatief grote HBO- en WO-opleidingen (minimaal 100 cases in totaal in 2003 en 2004). Uit dit bestand zijn aselect per opleiding deelbestanden aangemaakt met achtereenvolgens 100, 80, 60, 40, 30, 20, 15 en 10 cases per opleiding. Vervolgens zijn correlaties berekend tussen de scores op basis van 100 cases, en scores op basis van de kleinere steekproeven. ${ }^{2}$ Om een consistent beeld te

2. Voor de test maakt het niet uit dat de eenheden anders zijn dan de uiteindelijke rapportageeenheden. 
krijgen, is deze procedure 8 keer herhaald, en zijn de gemiddelde correlaties van die 8 tests berekend. De uitkomsten per onderwijsfunctie worden in figuur 2.1 gepresenteerd.

Figuur 2.1

Gevoeligheid voor aantal cases per rapportage-eenheid

kwalificatiefunctie

selectiefunctie
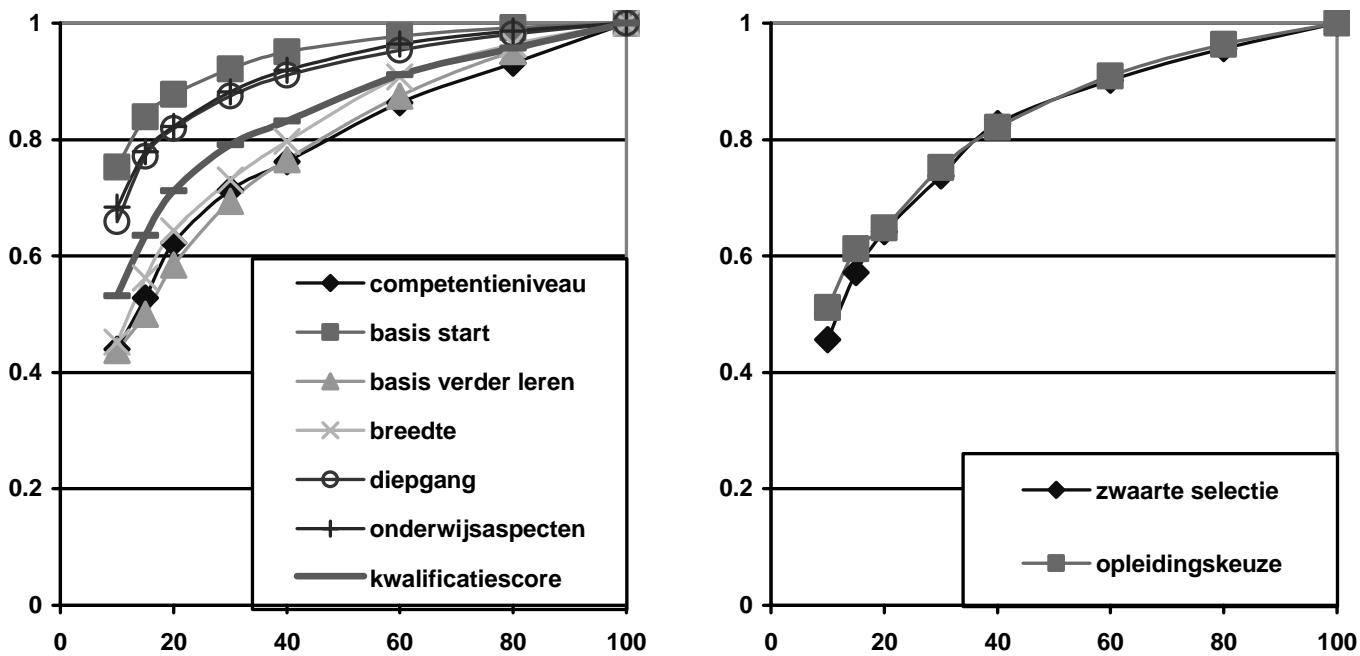

allocatiefunctie

extern rendement
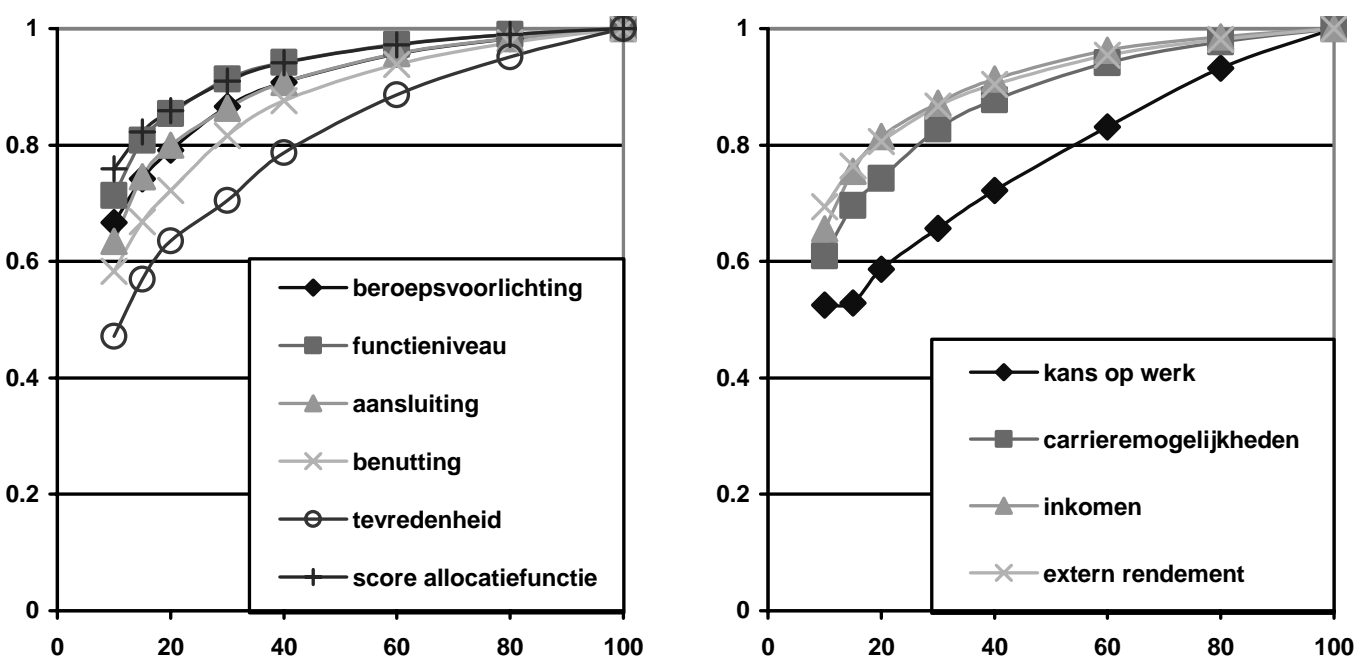

Zoals mag worden verwacht is de betrouwbaarheid lager bij een klein aantal cases per opleiding dan bij een groter aantal cases. ${ }^{3}$ Over het algemeen geldt dat de betrouwbaarheid sneller afneemt naarmate het aantal cases kleiner wordt. Wel is een duidelijk verschil te zien tussen de verschillende indicatoren voor wat betreft de gevoeligheid voor het aantal cases. Bij sommige indicatoren, zoals de mate waarin de opleiding een goede basis vormt om te

3. Bij deze test zijn HBO- en WO-opleidingen samengenomen. Aparte tests voor HBO en WO leveren een vergelijkbaar beeld op. 
starten op de arbeidsmarkt en het vereiste opleidingsniveau in de huidige functie, is zelfs bij slechts 10-15 cases sprake van een redelijke mate van betrouwbaarheid. Bij andere indicatoren, zoals de mate waarin de opleiding een goede basis vormt om verder te leren en de mate van tevredenheid met de huidige functie, is zelfs bij 40 cases sprake van een tamelijk lage correlatie met de score op basis van 100 cases. We komen zo meteen hierop terug.

De belangrijke vraag is natuurlijk welk niveau van betrouwbaarheid nog acceptabel wordt gevonden. Bij het beantwoorden van deze vraag zal een trade-off moeten worden gemaakt tussen betrouwbaarheid en volledigheid. Door een relatief hoge ondergrens in te stellen kan worden bewerkstelligd dat de gepresenteerde cijfers in hoge mate als betrouwbaar mogen worden beschouwd. In dat geval zal echter voor een groot aantal opleidingen niet, of slechts zeer onvolledig, kunnen worden gerapporteerd. Bij het nader bestuderen van de uitkomsten van deze tests valt op dat er een tamelijk groot verschil is tussen de betrouwbaarheid op basis van 15 cases, en de betrouwbaarheid op basis van 20 cases per rapportage-eenheid. Boven de 20 cases is de 'winst' meer gradueel. Het lijkt daarom raadzaam om een ondergrens van minimaal 20 cases te hanteren. ${ }^{4}$

\section{Effect van verdelingskenmerken}

Zoals eerder is opgemerkt, zijn sommige indicatoren gevoeliger voor het aantal cases dan anderen. Mogelijk hangt dit samen met bepaalde kenmerken van de verdeling van de scores per opleiding. Het zou bijvoorbeeld kunnen zijn dat scheefverdeelde variabelen gevoeliger zijn voor het aantal cases dan normaalverdeelde variabelen. Om dit na te gaan is gekeken naar de correlaties tussen enerzijds de gemiddelde correlatie tussen de cijfers op basis van 100 cases per opleiding en die op basis van 20 cases per opleiding, en anderzijds de scheefheid (absolute waarde), het gemiddelde, de standaardafwijking en de kurtosis ('gepiektheid') van de verdeling. Deze correlaties staan in tabel 2.2.

Tabel 2.2

Correlaties van verdelingskenmerken van kwaliteitsscores en de betrouwbaarheid van de cijfers op basis van 20 cases per rapportage-eenheid

Het meest bepalend voor de robuustheid van de cijfers is de standaardafwijking (spreiding) van de scores per opleiding op de betreffende indicatoren. Ook het gemiddelde en de

4. Deze ondergrens heeft betrekking op alle landelijke cijfers, en op de samengestelde rapportcijfers per instelling. De onderliggende cijfers voor de betreffende instelling worden altijd gerapporteerd. Deze cijfers worden echter grijs afgedrukt wanneer ze op minder dan 20 waarnemingen zijn gebaseerd. 
gepiektheid lijken met de robuustheid samen te hangen, maar dit komt omdat deze verdelingskenmerken ook met de spreiding samenhangen. In een multivariate regressie vergelijking blijft alleen het effect van de spreiding over. Dit betekent dat een score die op weinig cases is gebaseerd de werkelijke score slechter voorspelt naarmate de scores dichter bij elkaar liggen. Dit heeft als belangrijke implicatie dat de omvang van de fouten vrij gering zijn. In feite zijn de lage correlaties bij indicatoren zoals de mate waarin de opleiding een goede basis vormt om verder te leren een directe consequentie van de geringe verschillen tussen opleidingen op zulke indicatoren: in dat geval zullen zelfs kleine 'fouten' tot lage correlaties leiden. Er lijkt derhalve geen reden om te differentiëren tussen indicatoren voor wat de ondergrens betreft.

\section{Proporties of gemiddelden?}

De scores zoals ze nu zijn berekend, zijn gebaseerd op het percentage afgestudeerden per rapportage-eenheid dat een bepaalde norm haalt, bijvoorbeeld antwoordcategorie 3 of hoger op een vijfpuntsschaal. Voor schaal- en intervalvariabelen betekent dit dat er alleen gebruik wordt gemaakt van een beperkt deel van de variantie op individueel niveau. Hiervoor is bewust gekozen bij de ontwikkeling van het indicatorenstelsel: opleidingen worden in eerste instantie beoordeeld op basis van hun vermogen om een hoog percentage afgestudeerden 'over de streep' te halen. Bij gebruik van gemiddelden kan het voorkomen dat de slechte resultaten van de meerderheid van de afgestudeerden gecompenseerd worden door de zeer goede resultaten van een kleine groep afgestudeerden. Hoewel zulke cijfers voor excellentie ook relevant kunnen zijn, zou een dergelijke werkwijze een incentive kunnen geven voor opleidingen om minder aandacht te besteden aan hun minder sterke studenten.

Figuur 2.2

Gevoeligheid voor een laag aantal cases (20) per rapportage-eenheid: proporties versus gemiddelden

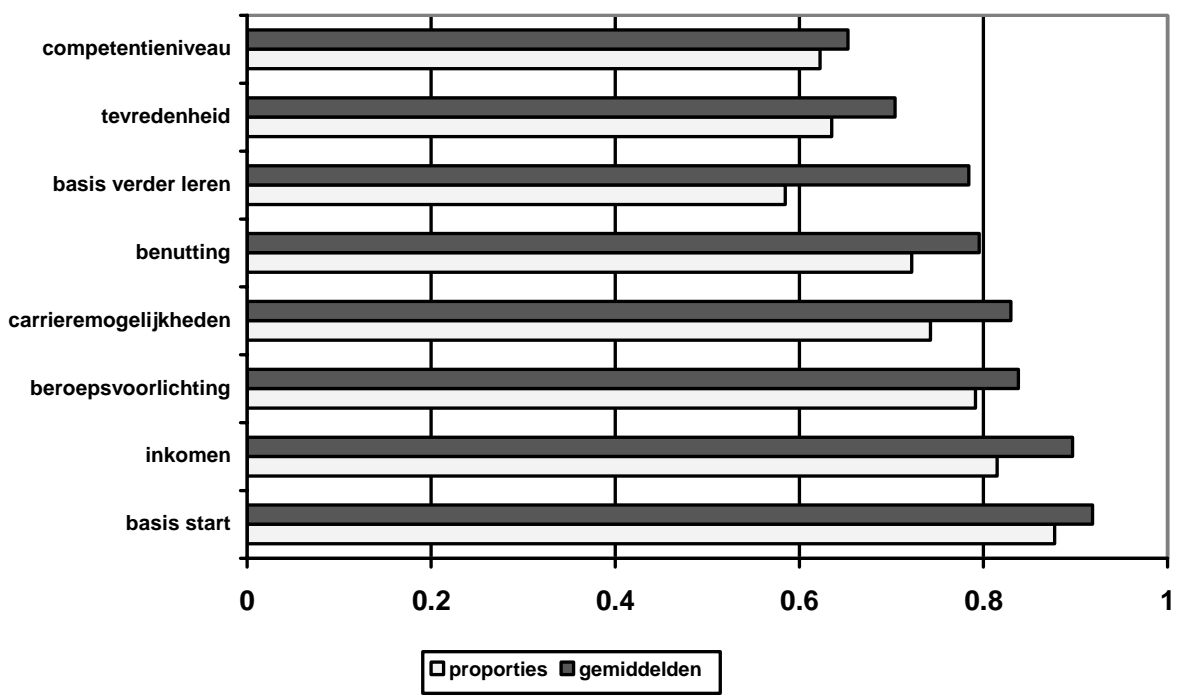

Toch is de vraag relevant of de scores op basis van het percentage per opleiding met een voldoende gevoeliger zijn voor het aantal cases dan scores die op gemiddelden van de originele variabelen zijn gebaseerd. Figuur 2.2 toont de correlaties tussen de cijfers op basis 
van 100 cases per opleiding en die op basis van 20 cases per opleiding, uitgaande van proporties respectievelijk gemiddelden (uiteraard alleen voor indicatoren waarbij een gemiddelde betekenis heeft).

Het is duidelijk dat proporties gevoeliger zijn dan gemiddelden, hoewel dit ook per indicator verschilt. Vooral bij de mate waarin de opleiding een goede basis vormt om verder te leren is het verschil groot. Dit heeft te maken met de verdeling van de originele variabele: een zeer hoog percentage van alle afgestudeerden (95\%) haalt de norm (minimaal 3 op een vijfpuntsschaal). Het grootste deel van de variantie (ook tussen opleidingen) zit tussen de antwoordcategorieën 3, 4 en 5.

Ondanks de wat grotere betrouwbaarheid van scores die op gemiddelden zijn gebaseerd, is dit op zichzelf geen reden om af te zien van cijfers die op proporties zijn gebaseerd. In een aantal gevallen is er zelfs geen keuze, omdat de oorspronkelijke variabele binair is. Bovendien lost het gebruik van gemiddelden het probleem van kleine aantallen niet geheel op: ook bij gemiddelden wordt de betrouwbaarheid snel minder bij kleine aantallen.

\section{Validiteitstesten}

Een sterke mate van betrouwbaarheid is een noodzakelijke, maar geen voldoende voorwaarde voor een bruikbaar indicatorenstelsel. Validiteit heeft betrekking op de vraag of we meten wat we beogen te meten (Baker, 1988). De meest fundamentele vorm van validiteit is de begripsvaliditeit: de validiteit ten opzichte van het begrip zelf (de Groot, 1981). Er zijn twee verschillende manieren om de begripsvaliditeit te 'toetsen'. De eenvoudigste manier is om de gebruikte maat kritisch tegen het licht te houden, en om te vragen of deze maat een goede weerspiegeling vormt van het betekenisdomein van het onderliggende concept. Dit wordt vaak aangeduid als inhoudsvaliditeit (de Groot, 1981; Bohrnstedt, 1983). Een tweede manier om de begripsvaliditeit te toetsen bestaat uit het vaststellen of de gebruikte maat correleert met andere indicatoren van hetzelfde of een vergelijkbaar concept. Dit wordt vaak in het Engels aangeduid als 'congruent validity', door de Groot (1981) vertaald als soortgenoot-validiteit.

Hoewel het toetsen van de soortgenoot-validiteit aan veel preciezere criteria - zoals correlatie- en schaalbaarheidscoëfficiënten - kan worden opgehangen dan het geval is bij inhoudsvaliditeit, is het altijd verstandig op beide manieren te toetsen. Het feit dat een aantal variabelen onderling sterk gecorreleerd is, biedt als zodanig geen garantie dat deze variabelen een goede weerspiegeling vormen van het begrip zoals bedoeld. Andersom geldt dat er situaties denkbaar zijn waar een aantal componenten van een overkoepelend begrip onderling niet - of zelfs negatief - gecorreleerd zijn. Dit laatste zou het geval kunnen zijn wanneer aannemelijk is dat er sprake is van een trade-off tussen twee of meer onderliggende items die worden gebruikt om een overkoepelend begrip te meten. Voorbeelden zijn de mate van tevredenheid over de breedte en de diepgang van een opleiding, of over de keuzemogelijkheden en samenhang van een onderwijsprogramma. Voor de kwalificatiefunctie van het onderwijs worden zowel de breedte als de diepgang als 
belangrijk beschouwd, ondanks het feit dat het moeilijk kan zijn om beide tegelijk te realiseren. Op soortgelijke wijze wordt bij de evaluatie van het onderwijsprogramma waarde gehecht aan zowel de keuzemogelijkheden als de samenhang, die bij de realisatie wellicht op gespannen voet met elkaar staan.

In deze paragraaf wordt om deze reden de begripsvaliditeit getoetst aan de hand van zowel de inhoudsvaliditeit als de soortgenoot-validiteit. De soortgenoot-validiteit wordt getoetst aan de hand van de onderliggende correlaties en de Cronbach's alpha (een maat voor de schaalbaarheid van een groep variabelen) van de bij een bepaald onderdeel behorende indicatoren te berekenen. Voor de kwalificatie- en allocatiefunctie en het externe rendement wordt gebruik gemaakt van data van 2003-2005, met een ondergrens van 100 cases per instelling. Voor de overige aspecten, die in 2005 voor het eerst zijn bevraagd, worden data uit 2005 gebruikt, met een ondergrens van 50 cases per instelling.

De kwalificatiefunctie draait om de vraag of het onderwijs de studenten afdoende heeft uitgerust met die competenties welke relevant zijn voor de doorstroming naar de arbeidsmarkt. Vanuit de inhoudsvaliditeit beredeneerd lijken de gebruikte indicatoren voor de kwalificatiefunctie een goede weerspiegeling van het begrip zoals bedoeld. De indicator van het competentieniveau is een directe indicator van de kwalificatiefunctie volgens deze definitie. De indicatoren voor de mate waarin de opleiding een goede basis vormde om te starten op de arbeidsmarkt respectievelijk om verder te leren geeft een nadere invulling van dit begrip vanuit het oogpunt van de korte- en lange termijndoelstellingen van het onderwijs. Tenslotte geeft het oordeel over de breedte en de diepgang van de opleiding aan of een goede balans is bereikt tussen het aanleren van een breed scala aan competenties en de mate van beheersing van die competenties.

Tabel 3.1 toont de correlaties tussen de indicatoren van de kwalificatiefunctie.

De meest opvallende uitkomst die uit tabel 3.1 naar voren komt is dat de cijfers voor voldoende competentieniveau niet of nauwelijks gecorreleerd zijn met de overige indicatoren van de kwalificatiefunctie. Alleen met de indicator van de gewenste diepgang van de opleiding is sprake van een tamelijk zwakke correlatie voor het totale $\mathrm{HO}$, die overigens niet significant is voor HBO en WO apart. Gezien de centrale rol van deze indicator van de kwalificatiefunctie is dit geen bevredigend resultaat. Van een trade-off met de andere indicatoren kan namelijk geen sprake zijn. De vraag blijt welke indicatoren wel en welke niet valide zijn. De overwegend positieve correlaties tussen de overige vier indicatoren lijken erop te wijzen dat deze over een hogere mate van validiteit beschikken. Ook wanneer we naar de 'beste' en 'slechtste' opleidingen op basis van competentieniveau en op basis van de samengestelde score van overige kwalificatieaspecten kijken (zie tabel 3.2), lijkt de ranking op basis van de andere aspecten geloofwaardiger. De conclusie lijkt gerechtvaardigd dat - in zijn huidige vorm tenminste - de indicator van voldoende competentieniveau niet geschikt is als kwaliteitsindicator. Het advies is dus om deze indicator vooralsnog uit de lijst van indicatoren te halen. 
Tabel 3.1

Correlaties tussen indicatoren van de kwalificatiefunctie

$\begin{array}{llll}a & b & c & d\end{array}$

a. competentieniveau

$\begin{array}{lll}\text { b. basis start } & \mathrm{HBO} & 0.02\end{array}$

WO $\quad-0.07$

HO Totaal $\quad-0.05$

c. basis verder leren

$\begin{array}{lrl}\text { HBO } & 0.15 & 0.67^{\star \star *} \\ \text { WO } & -0.04 & 0.80^{* \star *} \\ \text { HO Totaal } & 0.10 & 0.57^{* \star *}\end{array}$

d. breedte

$\mathrm{HBO}$

0.00

$0.62^{\star * *}$

$0.65^{\star \star *}$

WO

0.00

0.12

$0.37^{\star \star \star}$

HO Totaal

0.05

$0.39^{\star * *}$

$0.58^{\star \star *}$

e. diepgang

$\begin{array}{llllc}\text { HBO } & 0.00 & 0.24^{\star \star} & 0.32^{\star \star \star} & 0.26^{\star \star} \\ \text { WO } & 0.09 & 0.23^{\star \star} & 0.15 & -0.39 \\ \text { HO Totaal } & 0.15^{\star \star} & 0.16^{\star \star} & 0.42^{\star \star \star} & 0.10\end{array}$

Aantal cases: HBO 71; WO 57; HO Totaal 128

*: $p<0,10 ;{ }^{* \star}: p<0,05 ;{ }^{* \star} p<0,01$ (eenzijdige toets; alleen positieve correlaties gemarkeerd)

Nadere analyses maken overigens duidelijk dat het probleem grotendeels terug te voeren is op het individueel niveau, waar het eigen competentieniveau (de belangrijkste bouwsteen van deze indicator) slechts vrij zwak correleert met variabelen als de mate waarin een opleiding een goede basis bood om te starten en om verder te leren. Deze zwakke correlaties op individueel niveau worden nog zwakker en verliezen hun significantie wanneer op het niveau van opleidingen wordt geaggregeerd. Dit heeft voor een deel te maken met het geringe aantal cases op dit niveau, maar ook met het feit dat de correlaties op individueel niveau primair een reflectie zijn van verschillen binnen, en niet tussen, opleidingen. Overigens laten vergelijkbare data uit een internationaal onderzoek (REFLEX) ook lage correlaties op individueel niveau zien tussen deze kenmerken in de deelnemende landen (waaronder Nederland).

Van de andere indicatoren is de gewenste diepgang over de hele linie het zwakst gecorreleerd met de overige onderwijsaspecten. Bij WO is de gewenste diepgang alleen significant positief gecorreleerd met de mate waarin de opleiding een goede basis vormt om te starten, en is zelfs significant negatief gecorreleerd met de gewenste breedte. Dit suggereert dat bij WO-opleidingen sprake is van een trade-off tussen diepgang en breedte. Dit betekent geenzins dat de twee indicatoren niet valide zijn als component van de kwalificatiefunctie. Voor een evenwichtig oordeel hierover is juist van belang om rekening te houden met beide aspecten. Bij het HBO is overigens van een dergelijke trade-off geen sprake: er is zelfs een significant positieve correlatie tussen de score op breedte en de score op diepgang. Het is wel zo dat de correlaties tussen diepgang en de overige aspecten ook bij HBO opleidingen lager zijn dan de overige correlaties. Uit tabel 3.1 blijkt verder dat er bij 
WO opleidingen geen significante correlatie is tussen de score op breedte en de score op de mate waarin de opleiding een goede basis bood om te starten op de arbeidsmarkt. Net als bij de indicator van voldoende competentieniveau, zijn de bovengenoemde lage of negatieve correlaties voor een groot deel terug te voeren op het individueel niveau. De corresponderende correlaties op individueel niveau zijn allemaal significant positief, maar vrij zwak.

Een systematischer manier om naar de soortgenoot-validiteit te kijken is om na te gaan in hoeverre de items samen een betrouwbare schaal vormen. Als we naar de Cronbach's alpha kijken op basis van de vier onderwijsaspecten, valt op dat deze niet erg hoog is $(0,52$ voor het totale $\mathrm{HO}, 0,67$ voor $\mathrm{HBO}$, en 0,32 voor WO) (zie tabel 3.2). ${ }^{5}$ De vraag is of deze vrij lage schaalbaarheid te wijten is aan één van de indicatoren, en zo ja welke. Tabel 3.2 laat daarom ook de verandering in Cronbach's alpha zien wanneer we één voor één elk van de vier onderwijskenmerken weglaten.

Tabel 3.2

Schaalbaarheid (Cronbach's alpha) van onderwijskenmerken

\begin{tabular}{lccr} 
& HBO & WO & Totaal HO \\
\hline $\begin{array}{l}\text { Cronbach's alpha alle onderwijskenmerken } \\
\begin{array}{l}\text { Cronbach's alpha bij het weglaten van indicator: } \\
\text { b basis start }\end{array}\end{array}$ & 0,67 & 0,32 & 0,52 \\
- basis verder leren & 0,54 & $-0,36$ & 0,41 \\
- breedte & 0,62 & 0,18 & 0,41 \\
diepgang & 0,49 & 0,42 & 0,42 \\
& 0,70 & 0,36 & 0,56 \\
\hline
\end{tabular}

Voor het HBO en het totale HO geldt dat de Cronbach's alpha kleiner wordt wanneer een van de drie kenmerken basis om te starten, basis om verder te leren en breedte wordt weggelaten. Voor het WO geldt dat het weglaten van de indicator van de breedte tot een iets grotere Cronbach's alpha leidt. ${ }^{6}$ Voor alle groepen geldt dat het weglaten van de indicator voor de diepgang tot een lichte verbetering leidt. Het verschil is echter niet groot. Dit heeft te maken met de eerder geconstateerde lage correlaties tussen diepgang en de overige kenmerken. Op basis van de inhoudsvaliditeit kan echter worden beargumenteerd dat deze indicator zeer relevant is voor een goede meting is van de kwalificatiefunctie.

Het selectieproces is optimaal wanneer enerzijds de opleiding studenten trekt die over de juiste capaciteiten en belangstelling beschikken om de opleiding te volgen en anderzijds voldoende geselecteerd wordt op relevante competenties om het 'middelmatigheidsrisico' (Glebbeek, 1988) voor werkgevers te minimaliseren. Vanuit het perspectief van de

5. Het is denkbaar dat de relatief lage waarden van Cronbach's alpha te herleiden is tot het betrekkelijk klein aantal opleidingen. Een herhaling van de analyse op het niveau van individuele afgestudeerden leidt echter eerder tot een daling dan tot een stijging in de Cronbach's alpha. Dit geldt ook voor de andere onderwijsfuncties en evaluatieonderdelen.

6. De negatieve Cronbach's alpha bij WO als de indicator voor een goede start op de arbeidsmarkt wordt weggelaten, wijst op een negatieve covariantie tussen de drie overblijvende variabelen. 
inhoudsvaliditeit lijken de gebruikte indicatoren voor de selectiefunctie op zich te passen bij het begrip zoals bedoeld. De zwaarte van de selectie geeft aan of - gecorrigeerd voor het aanvangsniveau - de cijfertoekenning bij een opleiding voldoende streng is geweest. Het oordeel over de opleidingskeuze kan een indicatie zijn of de opleiding goed past bij de belangstelling van de studiekiezers. De moeilijkheidgraad geeft een indicatie van de selectie tijdens de opleiding, en het oordeel over de wijze van toetsen en beoordelen geeft aan in hoeverre deze selectie op een toepasselijke manier heeft plaatsgevonden. Er dient echter opgemerkt te worden dat alle vier van deze indicatoren slechts indirect zijn: in geen van de vier gevallen komt het begrip zoals gemeten ondubbelzinnig overeen met het begrip zoals bedoeld. Met het oog op de toekomst lijkt daarom wenselijk om na te gaan of directere indicatoren kunnen worden ontwikkeld voor de selectiefunctie.

Tabel 3.3 toont de correlaties tussen de indicatoren van de selectiefunctie.

Tabel 3.3

Correlaties tussen indicatoren van de selectiefunctie

a

b

C

a. zwaarte selectie

b. opleidingskeuze

WO $0,33^{\star \star}$

HO Totaal $0,18^{\star *}$

c. moeilijkheidsgraad

HBO

0,19 *

$0,66^{\star * *}$

WO

0,17

$0,55^{\star \star *}$

HO Totaal

0,19 **

$0,65^{\star \star *}$

d. toetsen

$\begin{array}{lccl}\text { HBO } & 0,24^{\star *} & 0,39 * \star * & 0,22^{\star *} \\ \text { WO } & -0,26 & -0,07 & 0,07 \\ \text { HO Totaal } & 0,13 & 0,39 * \star * & 0,26^{\star \star *}\end{array}$

Aantal cases: HBO 58; WO 32; HO Totaal 90

*: $p<0,10 ;{ }^{* *}: p<0,05 ;{ }^{* \star} p<0,01$ (eenzijdige toets; alleen positieve correlaties gemarkeerd)

Bij de selectiefunctie is voor het $\mathrm{HO}$ als geheel alleen de correlatie tussen de zwaarte van de selectie en de tevredenheid over de wijze van toetsen en beoordelen niet significant. Wanneer we HBO en WO apart bekijken wordt duidelijk dat bij HBO-opleidingen wel een significante correlatie bestaat tussen deze twee indicatoren. Bij de WO-opleidingen is zelfs sprake van een zwakke negatieve correlatie. In feite blijkt dat de tevredenheid over de wijze van toetsen en beoordelen met geen enkele van de overige selectiekenmerken is gecorreleerd bij WO-opleidingen. Bij HBO-opleidingen blijkt de zwaarte van de selectie juist het sterkst met dit kenmerk samen te hangen.

Tabel 3.4 laat de Cronbach's alpha zien voor de indicatoren die bij de selectiefunctie behoren. 
Tabel 3.4

Schaalbaarheid (Cronbach's alpha) van selectiekenmerken

\begin{tabular}{lrrr} 
& HBO & WO & Totaal HO \\
\hline $\begin{array}{l}\text { Cronbach's alpha alle selectiekenmerken } \\
\text { Cronbach's alpha bij het weglaten van indicator: }\end{array}$ & 0,62 & 0,30 & 0,62 \\
- zwaarte selectie & 0,68 & 0,39 & 0,69 \\
- opleidingskeuze & 0,45 & $-0,08$ & 0,41 \\
$-\quad$ moeilijkheidsgraad & 0,47 & $-0,06$ & 0,45 \\
- toetsen & 0,56 & 0,60 & 0,60
\end{tabular}

Vooral bij WO-opleidingen blijken de indicatoren van de selectiefunctie een uitermate zwakke schaal te vormen. Wanneer de indicator voor de wijze van toetsen en beoordelen wordt weggelaten blijkt dat de overige items bij WO-opleidingen een veel betere schaal vormen. Bij HBO-opleidingen, evenals bij het $\mathrm{HO}$ als geheel, wordt Cronbach's alpha juist hoger na het weglaten van de indicator van de zwaarte van de selectie. Uit de bespreking van de inhoudsvaliditeit kwam naar voren dat alle vier indicatoren op zich een belangrijk facet van de selectiefunctie afdekken, maar dat er reden was voor twijfels over de wijze waarop de indicatoren zijn gemeten. De betrekkelijk lage Cronbach's alpha heeft wellicht hier mee te maken. Bovendien is niet vanzelfsprekend dat de verschillende indicatoren sterk met elkaar hoeven samen te hangen. Opleidingen zouden bijvoorbeeld kunnen kiezen om zwaar te selecteren aan de poort, maar iets soepeler om te gaan met de selectie tijdens de opleiding, of juist andersom. Het lijkt derhalve niet verstandig om te streven naar een verhoging van de soortgenoot-validiteit door één van de indicatoren weg te laten. Veel beter is het om te werken aan betere maten voor de bestaande indicatoren.

De allocatiefunctie van het onderwijs betreft de vraag of het onderwijs de afgestudeerden op een adequate wijze toeleidt naar de arbeidsmarkt. Hierbij kunnen twee dimensies onderscheiden worden: ondersteuning bij de transitie van opleiding naar werk, en de mate waarin het gevonden werk past bij de opleiding (aans/uiting). Beide dimensies zijn door de gekozen indicatoren afgedekt: de ondersteuning door het oordeel over de beroepsvoorlichting en de aansluiting door de overige kenmerken.

In tabel 3.5 staan de correlaties tussen de indicatoren van de allocatiefunctie.

De verschillende indicatoren van de allocatiefunctie zijn in alle gevallen sterk met elkaar gecorreleerd. Dit geldt zowel voor het $\mathrm{HO}$ als geheel als voor HBO en WO apart. Tabel 3.6 laat de Cronbach's alpha zien voor de indicatoren die bij de allocatiefunctie behoren. 
Tabel 3.5

Correlaties tussen indicatoren van de allocatiefunctie

a $\quad$ b $\quad c \quad c \quad d$

(a. tevredenheid beroepsvoorlichting)

b. functieniveau

$\begin{array}{ll}\text { HBO } & 0,51^{\star \star \star} \\ \text { WO } & 0,63^{\star \star \star} \\ \text { HO Totaal } & 0,60^{\star \star \star}\end{array}$

c. aansluiting

$\begin{array}{lll}\text { HBO } & 0,71^{\star \star *} & 0,77^{\star \star \star} \\ \text { WO } & 0,66^{\star \star *} & 0,71^{\star \star \star} \\ \text { HO Totaal } & 0,62^{\star \star *} & 0,63^{\star \star \star}\end{array}$

d. benutting

\begin{tabular}{|c|c|c|c|}
\hline $\mathrm{HBO}$ & $0,70^{\star \star \star *}$ & $0,77^{\star \star \star}$ & $0,90^{\star * \star}$ \\
\hline WO & $0,66^{\star \star \star}$ & $0,73^{\star \star \star}$ & $0,94^{\star * \star}$ \\
\hline HO Totaal & $0,63^{\star \star *}$ & $0,67^{\star \star \star}$ & $0,92^{\star \star \star}$ \\
\hline
\end{tabular}

e. baantevredenheid

$\begin{array}{lllll}\text { HBO } & 0,65^{\star \star \star} & 0,76^{\star \star \star} & 0,86^{\star \star \star} & 0,86^{\star \star \star} \\ \text { WO } & 0,60^{\star \star \star} & 0,69^{\star \star \star} & 0,88^{\star \star \star} & 0,91^{\star \star \star} \\ \text { HO Totaal } & 0,60^{\star \star \star} & 0,68^{\star \star \star} & 0,86^{\star \star \star} & 0,87^{\star \star \star}\end{array}$

Aantal cases: HBO 77 WO 57; HO Totaal 134

*: $p<0,10 ;{ }^{* *}: p<0,05 ;{ }^{* \star} p<0,01$ (eenzijdige toets; alleen positieve correlaties gemarkeerd)

Tabel 3.6

Schaalbaarheid (Cronbach's alpha) van allocatiekenmerken

\begin{tabular}{llll} 
& HBO & WO & Totaal HO \\
\hline $\begin{array}{l}\text { Cronbach's alpha alle allocatiekenmerken } \\
\text { Cronbach's alpha bij het weglaten van indicator: }\end{array}$ & 0,91 & 0,90 & 0,88 \\
- tevredenheid beroepsvoorlichting & 0,91 & 0,88 & 0,87 \\
- functieniveau & 0,91 & 0,91 & 0,89 \\
a aansluiting & 0,85 & 0,85 & 0,83 \\
benutting & 0,87 & 0,85 & 0,84 \\
baantevredenheid & 0,90 & 0,88 & 0,87 \\
& & &
\end{tabular}

De indicatoren die bij de allocatie behoren, vormen samen een sterke schaal, zowel voor het $\mathrm{HO}$ als geheel als voor HBO en WO apart. In de meeste gevallen maakt het weinig uit als één van de indicatoren wordt weggelaten. Als het iets uitmaakt wordt de Cronbach's alpha meestal kleiner. Op basis van zowel de inhoudsvaliditeit als de soortgenoot-validiteit is er duidelijk geen enkele reden om te twijfelen aan de validiteit van de indicatoren van de allocatiefunctie.

Extern rendement kan worden gedefinieerd als de verhouding van kosten en opbrengsten van onderwijs die door individuen en de overheid gerealiseerd worden. Wij beperken ons hier tot het individueel extern rendement. Om het individueel extern rendement te berekenen, zou men de beschikking moeten hebben over zowel de individuele kosten voor 
het volgen van de opleiding (inclusief de opportuniteitskosten) als de totale opbrengsten over de levensloop. Echter de individuele kosten per opleiding zijn slechts deels bekend en voorzover ze bekend zijn betreft het vaak de kosten die niet variëren tussen opleidingen (bijv. collegegeld). Data over de opportuniteitskosten per opleiding ontbreken geheel, evenals de totale opbrengsten over de levensloop. De indicatoren hebben derhalve uitsluitend betrekking op de beoordeling van de opbrengsten van de opleiding. Inhoudelijk lijken de drie indicatoren een goede afdekking te geven van deze opbrengsten, die kunnen verschillen naarmate meer of minder afgestudeerden erin slagen om werk te vinden, en naarmate meer of minder van de werkende afgestudeerden goede carrièremogelijkheden hebben en/of behoorlijk verdienen.

In tabel 3.7 staan de correlaties tussen de indicatoren van het externe rendement.

Tabel 3.7

Correlaties tussen indicatoren van het externe rendement

a

b

(a. kans op werk)

b. carrièremogelijkheden

$\begin{array}{ll}\text { HBO } & 0,28^{\star \star \star} \\ \text { WO } & 0,72^{\star \star \star} \\ \text { HO Totaal } & 0,51^{\star \star \star}\end{array}$

c. uurloon

HBO

$0,68^{\star \star \star}$

$0,33^{\star \star *}$

WO

$0,72^{\star \star \star}$

$0,75^{\star \star \star}$

HO Totaal $\quad 0,69^{\star \star \star} \quad 0,48^{\star \star *}$

Aantal cases: HBO 76 WO 55 HO Totaal 131

*: $p<0,10 ; * *: p<0,05 ;{ }^{* *} p<0,01$ (eenzijdige toets; alleen positieve correlaties gemarkeerd)

De verschillende indicatoren van het externe rendement zijn in alle gevallen sterk met elkaar gecorreleerd. Dit geldt zowel voor het $\mathrm{HO}$ als geheel als voor HBO en WO apart. Wel blijken de correlaties beduidend hoger te zijn voor WO dan HBO, met name die tussen carrièremogelijkheden en de andere twee indicatoren. Tabel 3.8 laat de Cronbach's alpha zien voor de indicatoren die bij het externe rendement behoren.

Tabel 3.8

Schaalbaarheid (Cronbach's alpha) van indicatoren van het externe rendement

HBO WO Totaal HO

Cronbach's alpha alle kenmerken extern rendement Cronbach's alpha bij het weglaten van indicator:

- $\quad$ kans op werk

- carrièremogelijkheden

Totaal HO

- uurloon

$\begin{array}{lll}0,69 & 0,88 & 0,78 \\ & & \\ 0,48 & 0,85 & 0,64 \\ 0,77 & 0,80 & 0,78 \\ 0,44 & 0,82 & 0,66\end{array}$


De indicatoren die bij het externe rendement behoren vormen samen een redelijk sterke schaal, vooral voor het WO. Meestal leidt het weglaten van één indicator tot een verslechtering van de schaalbaarheid. De enige uitzondering is de indicator carrièremogelijkheden voor het HBO. Het weglaten van deze indicator zou echter tot een verarming van het begrip extern rendement leiden, omdat deze dan te zeer zou zijn gericht op de korte termijn. De indicator carrièremogelijkheden geeft de mogelijkheid voor opleidingen die hun afgestudeerden een iets minder goede start bieden op de arbeidsmarkt, dit enigszins te compenseren door betere perspectieven op de langere termijn. Er kan worden geconcludeerd dat alle drie indicatoren voor het externe rendement gehandhaafd dienen te worden.

Voor een uitgebreid overzicht van de dimensies die bij de onderdelen programma, inzet van personeel en voorzieningen wordt verwezen naar het 'Accreditatiekader bestaande opleidingen hoger onderwijs' van de NVAO (2003). Aan de hand van dit kader zal naast - en in sommige gevallen in plaats van - de bestaande indicatoren een aantal nieuwe vragen worden opgenomen in de vragenlijsten. Ter ondersteuning van dit proces worden de bestaande indicatoren getoetst in termen van hun soortgenoot-validiteit. In tabel 3.9 staan de correlaties tussen de indicatoren ten behoeve van de evaluatie van achtereenvolgens het programma, de inzet van personeel en de voorzieningen.

Tabel 3.9

Correlaties tussen indicatoren t.b.v. evaluatie

Programma Opbouw studieprogramma Keuzemogelijkheden

\begin{tabular}{llcc} 
Keuzemogelijkheden & HBO & 0,06 & \\
& WO & $0,28^{\star}$ & \\
& HO Totaal & $0,35^{\star \star \star}$ & \\
samenhang tussen vakken & HBO & $0,81^{\star \star \star}$ & 0,16 \\
& WO & $0,25^{\star}$ & $-0,44$ \\
& HO Totaal & $0,66^{\star \star \star}$ & 0,08 \\
\hline Inzet van personeel & & & $0,69^{\star \star \star}$ \\
studiebegeleiding & HBO & & $0,27^{\star}$ \\
& WO & & $0,45^{\star \star \star}$ \\
\hline Voorzieningen & HO Totaal & & huisvesting \\
\hline materiele voorzieningen & HBO & $0,27^{\star \star}$ \\
& WO & $0,24^{\star}$ \\
& HO Totaal & $0,31^{\star \star *}$
\end{tabular}

Aantal cases: HBO 60 WO 33; HO Totaal 93

${ }^{*}: p<0,10 ;{ }^{* *}: p<0,05 ;{ }^{* *} p<0,01$ (eenzijdige toets; alleen positieve correlaties gemarkeerd)

Bij het onderdeel 'programma' is er geen significante correlatie tussen samenhang tussen vakken en keuzemogelijkheden. Bij WO is de correlatie zelfs significant negatief. Op zich is dit niet onlogisch: hoe meer keuzemogelijkheden een opleiding aanbiedt, hoe moeilijker het wordt om de samenhang te bewaren. Dit hoeft geen probleem te zijn. De ene opleiding zou 
een hoge kwaliteit in de ogen van afgestudeerden kunnen bereiken vooral door veel keuzes aan te bieden, de andere door de interne coherentie te vergroten. Beide aspecten lijken belangrijk te zijn in termen van de kwaliteit van het programma als geheel. Overigens, voor HBO correleert keuzemogelijkheden ook niet meer significant met opbouw van het programma.

De twee indicatoren van het onderdeel inzet van personeel zijn tamelijk sterk met elkaar gecorreleerd, vooral bij HBO-opleidingen. De twee indicatoren van het onderdeel voorzieningen zijn matig met elkaar gecorreleerd.

Tabel 3.10 laat de Cronbach's alpha zien voor de indicatoren ten behoeve van de evaluatie.

Tabel 3.10

Schaalbaarheid (Cronbach's alpha) van evaluatiekenmerken

\begin{tabular}{lllr} 
& HBO & WO & Totaal HO \\
\hline $\begin{array}{l}\text { Cronbach's alpha alle programmakenmerken } \\
\text { Cronbach's alpha bij het weglaten van indicator: }\end{array}$ & 0,48 & $-0,13$ & 0,48 \\
$\quad \quad$ opbouw studieprogramma & 0,25 & $-1,13$ & 0,13 \\
$-\quad$ keuzemogelijkheden & 0,87 & 0,39 & 0,79 \\
samenhang tussen vakken & 0,09 & 0,33 & 0,41 \\
Cronbach's alpha kenmerken inzet van personeel & 0,81 & 0,38 & 0,61 \\
Cronbach's alpha kenmerken voorzieningen & 0,42 & 0,37 & 0,46
\end{tabular}

Het is duidelijk dat de items die bij het onderdeel programma behoren samen geen goede schaal vormen. Wanneer de indicator voor keuzemogelijkheden wordt weggelaten, vormen de overgebleven twee items een redelijk goede 'schaal', vooral bij HBO-opleidingen. De twee indicatoren van het onderdeel inzet van personeel vormen een goede schaal bij HBOopleidingen, en een iets minder goede schaal bij WO-opleidingen. De twee indicatoren van het onderdeel voorzieningen zijn slechts beperkt schaalbaar. Zoals eerder is opgemerkt, wordt aan de hand van het NVAO accreditatiekader gewerkt aan een systematische lijst van indicatoren voor de drie evaluatieonderdelen. Het lijkt derhalve voorbarig om aan de hand van deze analyse te streven naar een verhoging van de soortgenoot-validiteit door één of meerdere van de bestaande indicatoren weg te laten (wat overigens niet eens mogelijk is bij inzet van personeel en voorzieningen).

\section{Samenhang tussen functies}

Tabel 3.11 laat op basis van de 2005 data (ondergrens 50 cases) zien in hoeverre de scores van de verschillende functies met elkaar samenhangen. Vanuit het oogpunt van validiteit is het niet noodzakelijk dat alle samengestelde scores sterk met elkaar samenhangen. Bij sommige indicatoren zou echter het ontbreken van een correlatie aanleiding kunnen geven tot twijfels. Het is bijvoorbeeld aannemelijk dat afgestudeerden van opleidingen die goed scoren op de kwalificatiefunctie daarmee goed voorbereid zijn op de beroepspraktijk, en 
daarom vaak goed scoren op indicatoren van de allocatiefunctie en het externe rendement. Ook deze laatstgenoemde functies zouden naar verwachting met elkaar moeten samenhangen. $\mathrm{Er}$ is daarentegen geen sterke reden om te verwachten dat scores op de selectiefunctie iets zeggen over de andere functies, omdat een goede selectie evenzeer betrekking kan hebben op opleidingen die relatief licht zijn als op zware opleidingen. Wat betreft de relatie tussen de indicatoren van enerzijds de resultaten van het onderwijs en anderzijds de evaluatiekenmerken, is het aannemelijk dat een goede score op de kwalificatiefunctie samen zal gaan met een goede score op het onderdeel programma. Er is geen goede reden om a priori aan te nemen dat de andere onderdelen sterk met elkaar samenhangen.

Tabel 3.11

Correlaties tussen samengestelde scores, 2005 data

$\begin{array}{llllll}\text { a } & \text { b } & c & d & \text { e } & f\end{array}$

\begin{tabular}{|c|c|c|c|c|c|c|c|}
\hline \multirow[t]{3}{*}{ b. selectiefunctie } & $\mathrm{HBO}(\mathrm{N}=61)$ & $0,59 * \star \star$ & & & & & \\
\hline & WO (N=51) & $0,58^{* \star *}$ & & & & & \\
\hline & Totaal HO (N=112) & $0,62^{\star \star \star}$ & & & & & \\
\hline \multirow[t]{3}{*}{ c. allocatiefunctie } & $\mathrm{HBO}(\mathrm{N}=77)$ & $0,57^{* \star *}$ & $0,29 * \star *$ & & & & \\
\hline & WO (N=57) & $0,72^{\star \star \star}$ & $0,45^{\star \star \star}$ & & & & \\
\hline & Totaal HO (N=134) & $0,52^{\star \star \star}$ & $0,24^{\star \star \star}$ & & & & \\
\hline \multirow[t]{3}{*}{ d. extern rendement } & $\mathrm{HBO}(\mathrm{N}=77)$ & $0,59 * \star *$ & 0,06 & $0,61^{\star \star \star}$ & & & \\
\hline & WO $(N=57)$ & $0,72^{\star \star \star}$ & $0,39 * \star *$ & $0,75^{\star \star}$ & & & \\
\hline & Totaal HO (N=134) & $0,65^{\star \star \star}$ & $0,25^{\star \star \star}$ & $0,60 * \star *$ & & & \\
\hline \multirow[t]{3}{*}{ e. programma } & $\mathrm{HBO}(\mathrm{N}=77)$ & $0,26 * \star$ & $0,37^{\star \star \star}$ & $-0,10$ & $-0,12$ & & \\
\hline & WO (N=57) & $-0,12$ & 0,02 & $-0,30$ & $-0,27$ & & \\
\hline & Totaal HO (N=134) & $0,19 * *$ & $0,36 * \star \star$ & $-0,27$ & $-0,09$ & & \\
\hline \multirow[t]{3}{*}{ f. inzet van personeel } & HBO (N=77) & $0,16^{\star}$ & $0,48 * \star *$ & 0,01 & $-0,26$ & $0,43^{\star \star \star}$ & \\
\hline & WO (N=57) & 0,06 & 0,13 & $-0,27$ & $-0,15$ & $0,49 * \star \star$ & \\
\hline & Totaal HO (N=134) & $0,19 * *$ & $0,41^{\star \star \star}$ & $-0,18$ & $-0,14$ & $0,52^{\star \star \star}$ & \\
\hline \multirow[t]{3}{*}{ g. voorzieningen } & $\mathrm{HBO}(\mathrm{N}=77)$ & 0,11 & 0,06 & 0,15 & $0,29 * \star \star$ & 0,04 & 0,03 \\
\hline & WO (N=57) & 0,11 & 0,00 & $-0,17$ & 0,02 & $0,30 * \star$ & $0,40 * \star \star$ \\
\hline & Totaal HO $(\mathrm{N}=134)$ & $0,19 * *$ & $0,14^{*}$ & $-0,09$ & $0,18 * \star$ & $0,28 * \star \star$ & $0,30 * \star \star$ \\
\hline
\end{tabular}

${ }^{*}: p<0,10 ;{ }^{\star *}: p<0,05 ;{ }^{* \star} p<0,01$ (eenzijdige toets; alleen positieve correlaties gemarkeerd)

Zoals verwacht tonen de kwalificatiefunctie, allocatiefunctie en extern rendement een zeer sterke onderlinge samenhang. Tegen de verwachting in is de samenhang tussen de kwalificatiefunctie en het onderdeel programma niet sterk, en in het geval van WO opleidingen zelfs licht negatief. Enigszins onverwacht blijkt de selectiefunctie sterk samen te hangen met de kwalificatiefunctie en in iets mindere mate met de allocatiefunctie. Over de hele linie lijken de kwaliteitsscores voor de resultaten van het onderwijs (kwalificatie, selectie, allocatie en externe rendement) weinig samen te hangen met de cijfers t.b.v. de evaluatie van het programma, de inzet van personeel en de voorzieningen. Van de evaluatiekenmerken hangen de scores voor het programma en de inzet van personeel sterk met elkaar samen. 
Evenwichtigheid samengestelde indicatoren

Om te zien in hoeverre de score op de samengestelde indicatoren een evenwichtige weerspiegeling is van alle onderliggende indicatoren, zijn regressieanalyses gedraaid per functie. In tabel 3.12 staan de gestandaardiseerde coëfficiënten (bèta's), die een beeld van de mate waarin variantie (d.w.z. verschillen tussen opleidingen) in de samengestelde variabelen wordt bepaald door variantie in de verschillende componentindicatoren.

Tabel 3.12

Regressieanalyses per onderdeel

Indicator

Bèta

HBO WO Total

Kwalificatiefunctie

- $\quad$ Start op de arbeidsmarkt

$0,51 \quad 0,67 \quad 0,55$

- Verder leren

0,12

0,10

0,13

- Breedte

0,31

0,24

0,28

- Diepgang

0,37

0,49

0,46

Selectiefunctie

- Zwaarte selectie

0,39

0,53

0,39

- Opleidingskeuze

0,33

0,38

0,34

- Moeilijkheidsgraad

0,38

0,45

0,37

- Toetsen

0,37

0,39

0,37

Allocatiefunctie

- Tevredenheid beroepsvoorlichting 0,26

0,21

0,24

- Functieniveau

0,30

0,35

0,34

- Aansluiting

0,19

0,26

0,27

- Benutting

0,12

0,18

0,18

- Tevredenheid

0,13

0,12

Extern rendement

- Kans op werk

- Carrièremogelijkheden

0,34

0,29

0,32

0,38

0,37

0,40

- Loon

0,52

0,44

0,47

Programma

- Opbouw

0,32

0,37

0,30

- Keuzemogelijkheden

0,63

0,86

0,69

- Samenhang tussen vakken

0,42

0,45

0,35

Inzet van personeel

- Kwaliteit docenten

0,51

0,44

0,55

- $\quad$ Studiebegeleiding

0,58

0,79

0,62

Voorzieningen

- Huisvesting

- Materiële voorz.

0,70

0,75

0,68

0,55

0,51

0,55

Bij de kwalificatiefunctie wegen de start op de arbeidsmarkt en de diepgang duidelijk zwaarder mee dan de andere twee indicatoren. Dit komt omdat deze kenmerken de meeste 
variante vertonen. Bij de allocatiefunctie weegt baantevredenheid relatief licht, en bij het onderdeel programma wegen keuzemogelijkheden relatief zwaar. Voor de rest verschillen de coëfficiënten weinig van elkaar.

\section{Beoordeling van verschillen}

In de meeste gevallen zullen de scores die zijn berekend voor de eigen instelling niet identiek zijn aan de landelijke scores op dezelfde kenmerken (behalve in het triviale geval waar de betreffende opleiding nergens anders wordt aangeboden). Bij zeer kleine verschillen zal duidelijk zijn dat deze weinig te betekenen hebben: deze zijn waarschijnlijk toe te schrijven aan toeval, en zelfs wanneer het om echte verschillen zou gaan, zijn deze vanwege de kleine omvang niet erg relevant. Aan het andere uiterste bevinden zich verschillen die zo groot zijn dat ze - mits ze op minimaal 20 waarnemingen zijn gebaseerd duidelijk relevant zijn. Tussen deze uitersten bevindt zich echter een grijs gebied waarbinnen niet meteen duidelijk is of de verschillen betekenisvol zijn of niet.

Er zijn twee methoden die kunnen worden gebruikt om het verschil tussen instellings- en landelijke cijfers te beoordelen. De eenvoudigste methode is een minimumgrens te bepalen voor de procentuele grootte van het verschil tussen de twee cijfers. Het belangrijkste voordeel van deze methode is juist zijn eenvoud: mits beide kolommen minimaal 20 waarnemingen bevatten, kan worden volstaan met het berekenen van de omvang van het verschil. Het nadeel is dat het verder geen rekening houdt met het aantal waarnemingen waarop het verschil is gebaseerd. Bij een grote opleiding zal een waargenomen verschil van $10 \%$ eerder op een echt verschil zijn gebaseerd dan hetzelfde waargenomen verschil bij een kleine opleiding.

De tweede methode om het verschil te beoordelen is door middel van een significantietoets. Het belangrijkste voordeel van deze methode is dat er rekening wordt gehouden met het onderscheidingsvermogen, dat met opleidingsgrootte toeneemt. Behalve het feit dat deze methode een veel complexere berekening vereist dan de eerste methode, wordt er vaak op gewezen dat significantie niet per definitie gelijk staat aan relevantie. Bij een voldoende groot aantal waarnemingen zal elk verschil, hoe minuscuul ook, als significant worden aangemerkt, terwijl grotere - en dus relevantere - verschillen bij kleine opleidingen onopgemerkt blijven.

Om de relatie tussen significantie en relevantie in kaart te brengen, is het Chi-kwadraat uitgerekend voor verschillende combinaties van landelijk percentage, procentuele afwijking bij de eigen instelling, aantal cases landelijk, en aantal cases instelling. ${ }^{7}$ Algemeen geldt dat het chi-kwadraat positief samenhangt met de grootte van de afwijking tussen het landelijken het instellingspercentage, het aantal cases bij de instelling, de scheefheid van de verdeling van de variable en in mindere mate het aantal cases landelijk.

7. Een soortgelijk beeld ontstaat wanneer gebruik wordt gemaakt van een andere toetsingseenheid zoals een t-toets. 
Tabel 4.1 geeft een overzicht van het chi-kwadraat bij een scheve verdeling (landelijk 5\% voldoende), variërend op aantal procentpunten afwijking en aantal cases voor de eigen instelling. Het aantal cases landelijk is telkens 2 maal het aantal cases bij de eigen instelling.

Tabel 4.1

Chi-kwadraat bij verschillende combinaties van aantal cases en percentage voldoende eigen instelling, landelijk 5\% voldoende aantal cases eigen instelling

$\begin{array}{lllllll}10 & 20 & 30 & 40 & 50 & 100 & 200\end{array}$

\begin{tabular}{rrrrrrrr} 
Instellingspercentage: & & & & & & & \\
- $0 \%$ voldoende & 0.52 & 1.03 & 1.55 & 2.07 & 2.59 & 5.20 & 10.00 \\
- $1 \%$ voldoende & 0.30 & 0.60 & 0.91 & 1.21 & 1.51 & 3.00 & 6.00 \\
- $2 \%$ voldoende & 0.16 & 0.31 & 0.47 & 0.63 & 0.78 & 1.60 & 3.10 \\
- $4 \%$ voldoende & 0.06 & 0.13 & 0.19 & 0.26 & 0.32 & 0.60 & 1.30 \\
- $5 \%$ voldoende & 0.01 & 0.03 & 0.04 & 0.06 & 0.07 & 0.20 & 0.30 \\
- $6 \%$ voldoende & 0.00 & 0.00 & 0.00 & 0.00 & 0.00 & 0.00 & 0.00 \\
- $7 \%$ voldoende & 0.01 & 0.03 & 0.04 & 0.05 & 0.07 & 0.10 & 0.30 \\
- $8 \%$ voldoende & 0.05 & 0.10 & 0.15 & 0.20 & 0.25 & 0.50 & 1.00 \\
- $9 \%$ voldoende & 0.11 & 0.21 & 0.32 & 0.43 & 0.53 & 1.10 & 2.10 \\
- $10 \%$ voldoende & 0.18 & 0.36 & 0.54 & 0.72 & 0.90 & 1.80 & 3.60 \\
- $12 \%$ voldoende & 0.27 & 0.54 & 0.8 & 1.07 & 1.34 & 2.70 & 5.40 \\
- $13 \%$ voldoende & 0.37 & 0.74 & 1.11 & 1.47 & 1.84 & 3.70 & 7.40 \\
- $14 \%$ voldoende & 0.48 & 0.96 & 1.44 & 1.92 & 2.40 & 4.80 & 9.60 \\
\hline
\end{tabular}

Lichtgrijs=significant op 10\%; $\quad$ halfgrijs=significant op 5\%; $\quad$ donkergrijs=significant op 1\%

Bij opleidingen met 30 cases of minder moet het verschil met het landelijk percentage groter zijn dan 10 procentpunten (dat wil zeggen: meer dan 15\% voldoende hebben) zijn om significant te zijn zelfs op 10\% niveau. Bij opleidingen met 200 cases zou een afwijking naar beneden van 3 procentpunten (dwz: $2 \%$ voldoende) significant zijn op 10\% niveau, en van 5 procentpunten (dwz: 0\% voldoende) zelfs significant zijn op 1\% niveau. Een afwijking naar boven met hetzelfde aantal cases moet minimaal 4 procentpunten bedragen (dwz: $9 \%$ voldoende) om significant te zijn op 10\% niveau, en 6 procentpunten (dwz: 11\% voldoende) om significant te zijn op $1 \%$ niveau.

Tabel 4.2 bevat een overzicht van het Chi-kwadraat bij een gelijke (50-50) verdeling op landelijk niveau. 
Tabel 4.2

Chi-kwadraat bij verschillende combinaties van aantal cases en percentage voldoende eigen instelling, landelijk 50\% voldoende

aantal cases eigen instelling

$\begin{array}{lllllll}10 & 20 & 30 & 40 & 50 & 100 & 200\end{array}$

$\begin{array}{cccccccc}\text { Instellingspercentage: } & & & & & & \\ \text { • } 40 \% \text { voldoende } & 0.27 & 0.54 & 0.80 & 1.07 & 1.34 & 2.70 & 5.40 \\ \text { - } 41 \% \text { voldoende } & 0.22 & 0.43 & 0.65 & 0.87 & 1.08 & 2.20 & 4.30 \\ \text { - } 42 \% \text { voldoende } & 0.17 & 0.34 & 0.51 & 0.68 & 0.86 & 1.70 & 3.40 \\ \text { - } 44 \% \text { voldoende } & 0.13 & 0.26 & 0.39 & 0.52 & 0.65 & 1.30 & 2.60 \\ \text { - 45\% voldoende } & 0.10 & 0.19 & 0.29 & 0.38 & 0.48 & 1.00 & 1.90 \\ \text { - 46\% voldoende } & 0.07 & 0.13 & 0.20 & 0.27 & 0.33 & 0.70 & 1.30 \\ \text { - 47\% voldoende } & 0.04 & 0.09 & 0.13 & 0.17 & 0.21 & 0.40 & 0.90 \\ \text { - 49\% voldoende } & 0.02 & 0.05 & 0.07 & 0.10 & 0.12 & 0.20 & 0.50 \\ \text { - } 50 \% \text { voldoende } & 0.01 & 0.02 & 0.03 & 0.04 & 0.05 & 0.10 & 0.20 \\ & 0.00 & 0.01 & 0.01 & 0.01 & 0.01 & 0.00 & 0.10 \\ & 0.00 & 0.00 & 0.00 & 0.00 & 0.00 & 0.00 & 0.00\end{array}$

Lichtgrijs=significant op 10\%; halfgrijs=significant op 5\%; $\quad$ donkergrijs=significant op 1\%

Omdat het uitgangspunt bij tabel 4.2 precies $50 \%$ voldoende is op landelijk niveau, is de waarde van chi-kwadraat bij procentuele afwijkingen naar boven en beneden symmetrisch verdeeld. We laten daarom alleen de afwijkingen naar beneden zien. Bij opleidingen met 50 cases of minder moet het verschil met het landelijke percentage groter zijn dan 10 procentpunten (dat wil zeggen: minder dan $40 \%$ of meer dan $60 \%$ voldoende hebben) om significant te zijn zelfs op $10 \%$ niveau. Bij opleidingen met 200 cases zou een afwijking van 8 procentpunten (dwz: $42 \%$ of 58\% voldoende) significant zijn op $10 \%$ niveau, en van 9 procentpunten (dwz: $41 \%$ of $59 \%$ voldoende) significant zijn op 5\% niveau. Om significant te zijn op 1\% niveau bij 200 cases moet de afwijking meer dan 10 procentpunten zijn.

Op basis van deze uitkomsten lijkt weinig reden te zijn om te verwachten dat, als we uitgaan van significanties, niet-relevante afwijkingen ten onrechte worden aangemerkt als significant. Bij zowel een scheve als een gelijke verdeling zijn de kleinste verschillen die zelfs op $10 \%$ niveau significant zijn, behoorlijk groot. Het probleem lijkt eerder te zijn dat bij kleinere opleidingen de verschillen erg groot moeten zijn om als significant te worden aangemerkt. Dit probleem is in theorie op te lossen door van een vaste procentuele afwijking uit te gaan. Risico is dan (juist bij kleine opleidingen) dat betekenis wordt gehecht aan toevallige verschillen. Als we bedenken dat een chi-kwadraat van 0,45 overeenkomt met een $50 \%$ kans dat het verschil op toeval berust, zou dat ons dwingen tot een keuze tussen het accepteren van een groot foutenrisico bij kleine opleidingen, en de lat erg hoog leggen, waardoor alsnog weinig verschillen als 'goed' of 'slecht' worden aangemerkt (zelfs bij grote opleidingen). Het lijkt daarom beter om van significantie uit te gaan. 


\section{Literatuur}

Allen, J., G. Ramaekers, \& R. van der Velden (2005), Naar een indicatorenstelsel voor de resultaten van het onderwijs. Paper gepresenteerd op het DAIR Seminar, november 2005.

Allen, J., F. Cörvers, G. Ramaekers, \& R. van der Velden (2006), De arbeidsmarktpositie van afgestudeerden van het hoger beroepsonderwijs, HBO-monitor 2006, Den Haag: HBORaad.

Baker, T.L. (1988), Doing Social Research, New York, etc.: McGraw-Hill International Editions.

Bohrnstedt, G.W. (1983), Measurement. In P.H. Rossi, J.D. Wright \& A.B. Anderson (eds.), Handbook of Survey Research, New York: Academic.

Glebbeek, A.C. (1988), De arbeidsmarktpositie van opleidingen. Tijdschrift voor Arbeidsvraagstukken, 4, 75-89.

Groot, A.D. de (1981), Methodologie: Grondslagen van Onderzoek in de Gedragswetenschappen. The Hague: Mouton.

Nederlands-Vlaamse Accreditatie Organisatie (2003), Accreditatiekader bestaande opleidingen hoger onderwijs. Den Haag: NVAO.

Peschar, J. \& A. Wesselingh (2001), Onderwijssociologie, Groningen: Wolters-Noordhoff 


\section{Bijlage: Berekening kwaliteitsindicatoren}

Bij de berekening van de 'rapportcijfers' hebben we de volgende uitgangspunten gehanteerd:

1. Voor elk aspect (kwalificatie, selectie, allocatie, extern rendement, programma, personeel en voorzieningen) zijn meerdere indicatoren bepaald die gezamenlijk het begrip zo goed mogelijk afdekken.

2. Per indicator is een minimumwaarde bepaald. Waarden lager dan dit minimum geven aan dat de respondent de opleiding op dit aspect duidelijk als onvoldoende beschouwd. Voor 5-puntschalen geldt dat in de regel de neutrale middencategorie 3 als minimum wordt gehanteerd.

3. Vervolgens is per aspect het percentage afgestudeerden berekend dat op of boven het minimum zit.

4. Dit percentage is vervolgens omgezet in een rapportcijfer. Hierbij hebben we als norm gehanteerd dat minimaal $75 \%$ op of boven het minimum moet zitten om een 6 te kunnen krijgen. De formule om het percentage om te zetten in een rapportcijfer is: Rapportcijfer $=10-(100-$ Percentage $) * 4 / 25$.

5. Om te voorkomen dat cijfers beneden de 6 zwaarder kunnen meewegen dan cijfers boven de 6, zijn alle rapportcijfers lager dan 2 afgerond op 2,0.

6. Het uiteindelijke rapportcijfer bedraagt het gemiddelde van de onderliggende indicatoren.

7. In de rapportages voor hogescholen over individuele opleidingen worden rapportcijfers alleen berekend wanneer de onderliggende indicatoren op mimimaal 20 waarnemingen betrekking hebben. 


\section{Berekening indicatoren voor kwalificatie}

\begin{tabular}{|c|c|c|}
\hline Indicator & Berekeningswijze & Vragenlijst \\
\hline $\begin{array}{l}\text { Opleiding voldoende } \\
\text { basis om te starten op } \\
\text { de arbeidsmarkt }\end{array}$ & $\begin{array}{l}\text { Procentueel aandeel van de } \\
\text { afgestudeerden dat vindt dat de } \\
\text { opleiding een voldoende basis vormt } \\
\text { om te starten op de arbeidsmarkt (score } \\
3,4 \text { en } 5) \text {. } \\
\text { Dit percentage is als volgt omgezet in } \\
\text { een rapportcijfer: } 10-(100- \\
\text { Percentage)* } 4 / 25 \text {. }\end{array}$ & $\begin{array}{l}\text { In welke mate biedt uw HBO- } \\
\text { opleiding een goede basis om te } \\
\text { starten op de arbeidsmarkt? } \\
\text { helemaal niet <-> in sterke mate } \\
\begin{array}{lllll}1 & 2 & 3 & 4 & 5\end{array}\end{array}$ \\
\hline $\begin{array}{l}\text { Opleiding voldoende } \\
\text { basis om competenties } \\
\text { verder te ontwikkelen }\end{array}$ & $\begin{array}{l}\text { Procentueel aandeel van de } \\
\text { afgestudeerden dat vindt dat de } \\
\text { opleiding een voldoende basis vormt } \\
\text { om kennis en vaardigheden verder te } \\
\text { ontwikkelen (score } 3,4 \text { en } 5 \text { ). } \\
\text { Dit percentage is als volgt omgezet in } \\
\text { een rapportcijer: } 10-(100- \\
\text { Percentage) }{ }^{\star} 4 / 25 \text {. }\end{array}$ & $\begin{array}{l}\text { In welke mate biedt uw HBO- } \\
\text { opleiding een goede basis voor } \\
\text { het verder ontwikkelen van } \\
\text { kennis en vaardigheden? } \\
\text { helemaal niet <-> in sterke mate } \\
\begin{array}{llll}1 & 2 & 3 & 4\end{array}\end{array}$ \\
\hline $\begin{array}{l}\text { Opleiding voldoende } \\
\text { breed }\end{array}$ & $\begin{array}{l}\text { Procentueel aandeel van de } \\
\text { afgestudeerden dat de opleiding } \\
\text { voldoende breed vindt (score } 3 \text { en } 4) .8 \\
\text { Dit percentage is als volgt omgezet in } \\
\text { een rapportcijfer: } 10-(100- \\
\text { Percentage })^{\star} 4 / 25 \text {. }\end{array}$ & 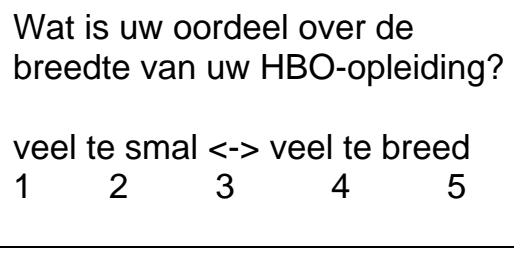 \\
\hline $\begin{array}{l}\text { Opleiding voldoende } \\
\text { diepgang }\end{array}$ & $\begin{array}{l}\text { Procentueel aandeel van de } \\
\text { afgestudeerden dat van oordeel is dat } \\
\text { de opleiding voldoende diepgang heeft } \\
\text { (score } 3,4 \text { en } 5) \text {. } \\
\text { Dit percentage is als volgt omgezet in } \\
\text { een rapportcijfer: } 10 \text {-(100- } \\
\text { Percentage })^{*} 4 / 25 \text {. }\end{array}$ & 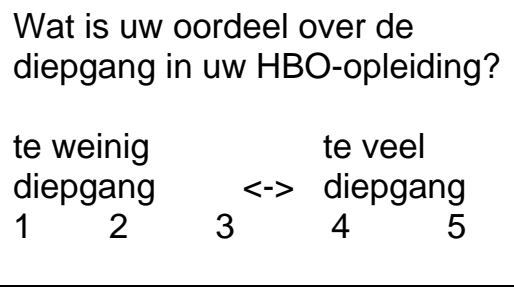 \\
\hline $\begin{array}{l}\text { Eindbeoordeling } \\
\text { kwalificatie }\end{array}$ & $\begin{array}{l}\text { Het gemiddelde van de } \\
\text { bovengenoemde } 4 \text { indicatoren voor de } \\
\text { kwalificatie. }\end{array}$ & \\
\hline
\end{tabular}

Naast de bovengenoemde indicatoren is ook nog een indicator 'competentieniveau' ontwikkeld, die uiteindelijk niet is opgenomen in de eindbeoordeling van de kwalificatiefunctie. Het betreft de volgende competenties:

- kennis van uw eigen vakgebied

- kennis van andere vakgebieden

- vermogen om uw vakkennis in de praktijk toe te passen

8. Nadere analyse wijst uit dat de scores 3 en 4 samenhangen met een goede beoordeling van andere aspecten van de opleiding. Wanneer de opleiding als veel te breed wordt beschouwd (score 5) hangt dit echter negatief samen met de andere oordelen. Het zelfde geldt als de opleiding als te smal wordt beschouwd (scores 1 en 2). 
- vermogen om informatie- en communicatietechnologie te gebruiken

- vermogen om in buitenlandse talen te communiceren

- vermogen om informatie te vergaren

- vermogen om problemen en kansen te signaleren

- vermogen om verbanden te leggen tussen verschillende zaken

- vermogen om hoofd- van bijzaken te onderscheiden

- vermogen om logisch te redenen

- vermogen om conform budget, planning of richtlijnen te werken

- vermogen om onder druk goed te functioneren

- vermogen om knopen door te hakken

- vermogen om nieuwe ideeën en oplossingen te bedenken

- vermogen om nieuwe dingen te leren

- vermogen om aan anderen duidelijk te maken wat $u$ bedoelt

- vermogen om productief met anderen samen te werken

- vermogen om capaciteiten van anderen aan te spreken

- vermogen om zelfstandig de werkzaamheden uit te voeren

- bereidheid om uw nek uit te steken

- bereidheid om ideeën van uzelf en anderen ter discussie te stellen

- bereidheid om op te komen voor uw eigen standpunt

- bereidheid om begrip te tonen voor andere standpunten

De berekening van de variabele competentieniveau is als volgt:

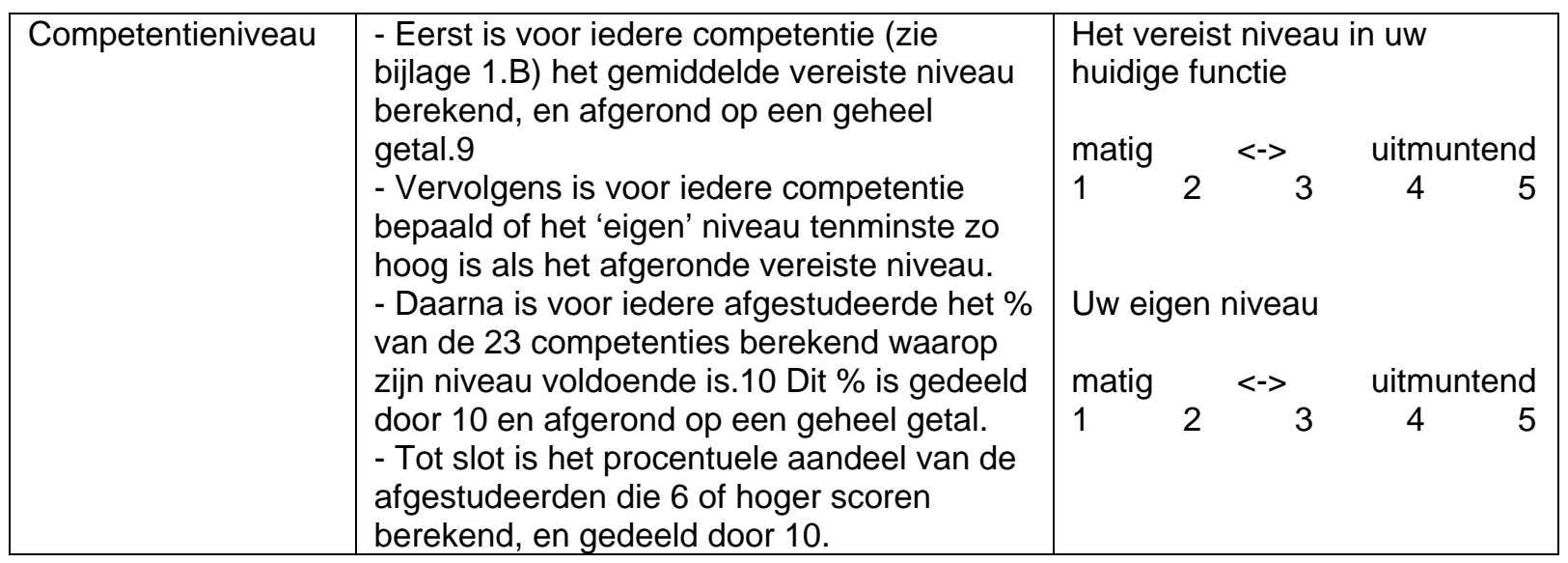

9. De berekening van het vereiste niveau is beperkt tot afgestudeerden die in hun kerndomein werken, dat wil zeggen in functies waarvoor het eigen opleidingsniveau én de eigen (of een verwante) opleidingsrichting door de werkgever is vereist.

10. Afgestudeerden die bij $>5$ competenties het 'eigen' niveau niet hebben aangegeven, zijn bij de berekening niet meegenomen. 


\section{Berekening indicatoren voor selectie}

\begin{tabular}{|c|c|c|}
\hline Indicator & Berekeningswijze & Vragenlijst \\
\hline $\begin{array}{l}\text { Cijfertoekenning } \\
\text { voldoende } \\
\text { streng }\end{array}$ & $\begin{array}{l}\text { Gebaseerd op een vergelijking per } \\
\text { afgestudeerde van het gemiddelde } \\
\text { examenciffer in het hbo en het } \\
\text { gemiddelde eindexamencijfer in het } \\
\text { havo.11 Berekend is het procentuele } \\
\text { aandeel van de afgestudeerden waarbij } \\
\text { het examencijfer in het hbo gelijk is aan } \\
\text { of lager is dan het eindexamencijfer in } \\
\text { het havo. } \\
\text { Dit percentage is als volgt omgezet in } \\
\text { een rapportcijfer: } 10-(100- \\
\text { Percentage })^{\star} 4 / 25 \text {. }\end{array}$ & $\begin{array}{l}\text { Gemiddeld eindexamencijfer in het } \\
\text { havo } \\
\begin{array}{lllllllll}6 & 6^{1 / 2} & 7 & 71 / 2 & 8 & 81 / 2 & 9 & 91 / 2 & 10 \\
\text { Gemiddeld examencijfer hbo } \\
6 \\
66^{1 / 2} & 7 & 71 / 2 & 8 & 81 / 2 & 9 & 91 / 2 & 10\end{array}\end{array}$ \\
\hline $\begin{array}{l}\text { Opleiding } \\
\text { voldoende } \\
\text { zwaar }\end{array}$ & $\begin{array}{l}\text { Procentueel aandeel van de } \\
\text { afgestudeerden dat de opleiding } \\
\text { voldoend moeilijk vindt (score } 3,4 \text { en } \\
5 \text { ). } \\
\text { Dit percentage is als volgt omgezet in } \\
\text { een rapportcijfer: } 10-(100- \\
\text { Percentage) } 4 / 25 \text {. }\end{array}$ & $\begin{array}{l}\text { Wat is uw oordeel over de } \\
\text { moeilijkheidsgraad van uw HBO- } \\
\text { opleiding? } \\
\text { Niet hoog genoeg <-> veel te hoog } \\
1 \quad 2 \quad 3 \quad 4 \quad 5\end{array}$ \\
\hline $\begin{array}{l}\text { Oordeel wijze } \\
\text { van toetsen en } \\
\text { beoordelen }\end{array}$ & $\begin{array}{l}\text { Procentueel aandeel van de } \\
\text { afgestudeerden dat een rapportcijfer } \\
\text { van } 6 \text { of hoger toekent aan de wijze van } \\
\text { toetsen en beoordelen. } \\
\text { Dit percentage is als volgt omgezet in } \\
\text { een rapportcijfer: } 10-(100- \\
\text { Percentage })^{\star} 4 / 25 \text {. }\end{array}$ & $\begin{array}{l}\text { Geef een rapportcijfer voor de } \\
\text { hieronder genoemde aspecten van de } \\
\text { door u gevolgde HBO-opleiding. } \\
\text { "Wijze van toetsen en beoordelen" } \\
\text { Geef een afgerond cijfer tussen } 1 \text { en } \\
10 .\end{array}$ \\
\hline $\begin{array}{l}\text { Opleiding } \\
\text { opnieuw kiezen }\end{array}$ & $\begin{array}{l}\text { Procentueel aandeel van de } \\
\text { afgestudeerden dat achteraf bezien } \\
\text { opnieuw voor dezelfde opleiding aan } \\
\text { dezelfde onderwijsinstelling zou kiezen. } \\
\text { Dit percentage is als volgt omgezet in } \\
\text { een rapportcijfer: } 10-(100- \\
\text { Percentage })^{\star} 4 / 25 \text {. }\end{array}$ & $\begin{array}{l}\text { Zou u, achteraf gezien, de door } u \\
\text { gevolgde HBO opleiding opnieuw } \\
\text { kiezen? } \\
1 \text { ja, dezelfde opleiding aan dezelfde } \\
\text { hogeschool } \\
2 \text { ja, dezelfde opleiding maar, aan een } \\
\text { andere hogeschool } \\
3 \text { nee, een andere opleiding, namelijk: } \\
\ldots \ldots \ldots \\
4 \text { nee, ik zou niet gaan studeren }\end{array}$ \\
\hline $\begin{array}{l}\text { Eindbeoordeling } \\
\text { selectie }\end{array}$ & $\begin{array}{l}\text { Het gemiddelde van de } \\
\text { bovengenoemde } 4 \text { indicatoren voor } \\
\text { selectie. }\end{array}$ & \\
\hline
\end{tabular}

11. Omdat eindexamencijfers van vwo'ers, havisten en mbo'ers onderling niet vergeleken kunnen worden, is deze berekening uitsluitend uitgevoerd voor hbo'ers met havo als hoogst voltooide vooropleiding. 


\section{Berekening indicatoren voor allocatie}

\begin{tabular}{|c|c|c|}
\hline Indicator & Berekeningswijze & Vragenlijst \\
\hline $\begin{array}{l}\text { Tevreden over } \\
\text { beroepsvoorlichting }\end{array}$ & $\begin{array}{l}\text { Procentueel aandeel van de } \\
\text { afgestudeerden dat een rapportcijfer } \\
\text { van } 6 \text { of hoger toekent aan de } \\
\text { beroepsvoorlichting. } \\
\text { Dit percentage is als volgt omgezet in } \\
\text { een rapportcijfer: } 10-(100- \\
\text { Percentage })^{\star} 4 / 25 \text {. }\end{array}$ & $\begin{array}{l}\text { Geef een rapportcijfer voor de } \\
\text { hieronder genoemde aspecten van de } \\
\text { door u gevolgde HBO-opleiding. } \\
\text { "Voorlichting over uw } \\
\text { beroepsmogelijkheden" } \\
\text { Geef een afgerond cijfer tussen } 1 \text { en } \\
10 .\end{array}$ \\
\hline $\begin{array}{l}\text { Functieniveau past } \\
\text { bij } \\
\text { opleidingsniveau }\end{array}$ & $\begin{array}{l}\text { Procentueel aandeel van de betaald } \\
\text { werkende afgestudeerden dat een } \\
\text { baan heeft op minstens hbo-niveau } \\
\text { (score } 1 \text { en } 2 \text { ). } \\
\text { Dit percentage is als volgt omgezet in } \\
\text { een rapportcijfer: } 10-(100- \\
\text { Percentage) } 4 / 25 \text {. }\end{array}$ & 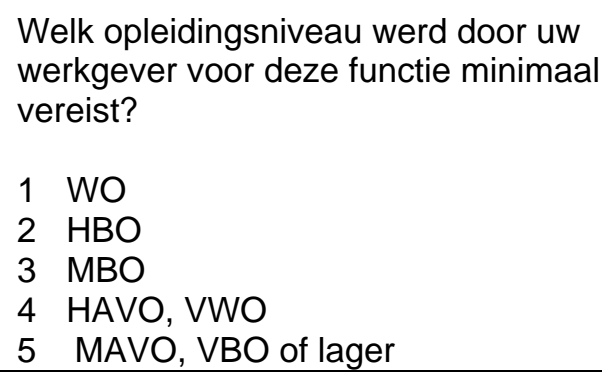 \\
\hline $\begin{array}{l}\text { Voldoende } \\
\text { aansluiting } \\
\text { opleiding-werk }\end{array}$ & $\begin{array}{l}\text { Procentueel aandeel van de betaald } \\
\text { werkende afgestudeerden dat een } \\
\text { baan heeft die 'voldoende' of 'goed' } \\
\text { aansluit bij de opleiding (score } 3 \text { en } 4) \text {. } \\
\text { Dit percentage is als volgt omgezet in } \\
\text { een rapportcijfer: } 10-(100- \\
\text { Percentage) } 4 / 25 \text {. }\end{array}$ & $\begin{array}{l}\text { Hoe sluit uw functie aan op uw HBO- } \\
\text { opleiding? } \\
1 \text { slecht } \\
2 \text { matig } \\
3 \text { voldoende } \\
4 \text { goed }\end{array}$ \\
\hline $\begin{array}{l}\text { Voldoende } \\
\text { benutting van } \\
\text { capaciteiten }\end{array}$ & $\begin{array}{l}\text { Procentueel aandeel van de betaald } \\
\text { werkende afgestudeerden dat } \\
\text { aangeeft dat hun capaciteiten } \\
\text { voldoende worden benut (score } 3,4 \\
\text { en } 5 \text { ) } \\
\text { Dit percentage is als volgt omgezet in } \\
\text { een rapportcijfer: } 10-(100- \\
\text { Percentage) } \star 4 / 25 \text {. }\end{array}$ & $\begin{array}{l}\text { In welke mate worden uw capaciteiten } \\
\text { in uw huidige functie benut? } \\
\text { helemaal niet <-> in sterke mate } \\
\begin{array}{lllll}1 & 2 & 3 & 4 & 5\end{array}\end{array}$ \\
\hline $\begin{array}{l}\text { Tevreden met } \\
\text { huidige functie }\end{array}$ & $\begin{array}{l}\text { Procentueel aandeel van de betaald } \\
\text { werkende afgestudeerden dat } \\
\text { tevreden is met de functie (score } 3,4 \\
\text { en } 5 \text { ), gedeeld door } 10 \text {. } \\
\text { Dit percentage is als volgt omgezet in } \\
\text { een rapportcijfer: } 10-(100- \\
\text { Percentage) } 4 / 25 \text {. }\end{array}$ & $\begin{array}{l}\text { Hoe tevreden bent u met uw huidige } \\
\text { functie? } \\
\text { zeer ontevreden <-> } \\
112 \text { zeer tevreden } \\
2 \quad 3 \quad 4 \quad 5\end{array}$ \\
\hline $\begin{array}{l}\text { Eindbeoordeling } \\
\text { allocatie }\end{array}$ & $\begin{array}{l}\text { Het gemiddelde van de boven- } \\
\text { genoemde } 5 \text { indicatoren voor } \\
\text { allocatie. }\end{array}$ & \\
\hline
\end{tabular}




\section{Berekening indicatoren voor extern rendement}

\begin{tabular}{|c|c|c|}
\hline Indicator & Berekeningswijze & Vragenlijst \\
\hline Werkloosheid & $\begin{array}{l}\text { Eerst is het } \\
\text { werkloosheidspercentage bepaald } \\
\text { onder de afgestudeerden. Dit betreft } \\
\text { het aantal afgestudeerden dat op } \\
\text { zoek is naar betaald werk en minder } \\
\text { dan } 12 \text { uur per week betaald } \\
\text { werkzaam is, gedeeld door het } \\
\text { aantal afgestudeerden dat tot de } \\
\text { beroepsbevolking behoort } \\
\text { (werkenden en werklozen). } \\
\text { Dit percentage is als volgt omgezet } \\
\text { in een rapportcijfer: } 10- \\
\text { (Percentage })^{\star} 4 / 7,5 \text {. } \\
\text { Hierdoor scoort bijvoorbeeld } 2 \% \\
\text { werkloosheid een } 8,9 ; 5 \% \\
\text { werkloosheid een } 7,3 \text { en } 10 \% \\
\text { werkloosheid een } 4,7 .\end{array}$ & $\begin{array}{l}\text { Heeft u op dit moment betaald werk? } \\
1 \text { ja } \\
2 \text { nee } \\
\text { Zoekt u op dit moment (ander) } \\
\text { betaald werk? } \\
1 \text { ja } \\
2 \text { nee } \\
\text { Gemiddelde arbeidsuren } \\
\text { (leraren: } 1 \text { lesuur is } 1,5 \text { arbeidsuur) } \\
\text { Reguliere-/contracturen in } \\
\text { hoofdfunctie } \\
\text {.......... uur per week } \\
\text { Overuren in hoofdfunctie } \\
\ldots \ldots \ldots . . . \text { uur per week } \\
\text { Uren in andere betaalde baan/banen } \\
\text {........... uur per week }\end{array}$ \\
\hline Bruto uurloon & $\begin{array}{l}\text { Procentueel aandeel van uurlonen } \\
\text { boven drempelinkomen voor hbo'ers. } \\
\text { Eerst is een norminkomen voor een } \\
\text { gemiddelde hbo'er berekend op } \\
\text { basis van het aantal jaren scholing } \\
\text { en leeftijd. Het drempelinkomen is } \\
\text { het norminkomen verminderd met } \\
\text { het inkomen dat hoort bij twee jaren } \\
\text { scholing. Het drempelinkomen van } \\
\text { hbo'ers bedraagt } € 9,96 \text { per uur. In } \\
\text { de praktijk betekent dit dat het } \\
\text { drempelinkomen dichter bij een mbo- } \\
\text { dan bij een hbo-salaris zit. } \\
\text { Dit percentage is als volgt omgezet } \\
\text { in een rapportcijfer: } 10-(100- \\
\text { Percentage })^{\star} 4 / 25 \text {. }\end{array}$ & $\begin{array}{l}\text { Bruto inkomen volgens contracturen } \\
\text { (inclusief toeslagen) in hoofdfunctie } \\
\text { Ongeveer } € \ldots . . . . . . . . \text { per maand } \\
\text { Gemiddelde arbeidsuren } \\
\text { (leraren: } 1 \text { lesuur is } 1,5 \text { arbeidsuur) } \\
\text { Reguliere-/contracturen in } \\
\text { hoofdfunctie } \\
\ldots \ldots \ldots . . . \text { uur per week }\end{array}$ \\
\hline $\begin{array}{l}\text { Voldoende } \\
\text { carrièremogelijkheden }\end{array}$ & $\begin{array}{l}\text { Procentueel aandeel van de betaald } \\
\text { werkende afgestudeerden dat } \\
\text { aangeeft dat de functie voldoende } \\
\text { carrièremogelijkheden biedt (score } 3, \\
4 \text { en } 5) \text {. } \\
\text { Dit percentage is als volgt omgezet } \\
\text { in een rapportcijfer: } 10-(100- \\
\text { Percentage)*4/25. }\end{array}$ & $\begin{array}{l}\text { Biedt uw functie goede } \\
\text { carrièremogelijkheden? } \\
\text { nauwelijks } \\
\begin{array}{llllc}1 & < & 3 & 4 & 5\end{array}\end{array}$ \\
\hline $\begin{array}{l}\text { Eindbeoordeling } \\
\text { extern rendement }\end{array}$ & $\begin{array}{l}\text { Het gemiddelde van de } \\
\text { bovengenoemde } 3 \text { indicatoren voor } \\
\text { het externe rendement. }\end{array}$ & \\
\hline
\end{tabular}




\section{Berekening indicatoren voor oordeel programma}

\begin{tabular}{|c|c|c|}
\hline Indicator & Berekeningswijze & Vragenlijst \\
\hline $\begin{array}{l}\text { Oordeel opbouw } \\
\text { studieprogramma }\end{array}$ & $\begin{array}{l}\text { Procentueel aandeel van de } \\
\text { afgestudeerden dat een rapportcijfer } \\
\text { van } 6 \text { of hoger toekent aan de } \\
\text { opbouw van het studieprogramma. } \\
\text { Dit percentage is als volgt omgezet in } \\
\text { een rapportcijfer: } 10-(100- \\
\text { Percentage)*4/25. }\end{array}$ & $\begin{array}{l}\text { Geef een rapportcijfer voor de } \\
\text { hieronder genoemde aspecten van de } \\
\text { door u gevolgde HBO-opleiding. } \\
\text { "Opbouw van het studieprogramma" } \\
\text { Geef een afgerond cijfer tussen } 1 \text { en } \\
10 .\end{array}$ \\
\hline $\begin{array}{l}\text { Oordeel } \\
\text { keuzemogelijkheden } \\
\text { in studie }\end{array}$ & $\begin{array}{l}\text { Procentueel aandeel van de } \\
\text { afgestudeerden dat een rapportcijfer } \\
\text { van } 6 \text { of hoger toekent aan de } \\
\text { keuzemogelijkheden in de studie. } \\
\text { Dit percentage is als volgt omgezet in } \\
\text { een rapportcijfer: } 10-(100- \\
\text { Percentage)*4/25. }\end{array}$ & $\begin{array}{l}\text { Geef een rapportcijfer voor de } \\
\text { hieronder genoemde aspecten van de } \\
\text { door u gevolgde HBO-opleiding. } \\
\text { "Keuzemogelijkheden in studie" } \\
\text { Geef een afgerond cijfer tussen } 1 \text { en } \\
10 .\end{array}$ \\
\hline $\begin{array}{l}\text { Oordeel samenhang } \\
\text { tussen vakken }\end{array}$ & $\begin{array}{l}\text { Procentueel aandeel van de } \\
\text { afgestudeerden dat een rapportcijfer } \\
\text { van } 6 \text { of hoger toekent aan de } \\
\text { samenhang tussen vakken. } \\
\text { Dit percentage is als volgt omgezet in } \\
\text { een rapportcijfer: } 10-(100- \\
\text { Percentage)*4/25. }\end{array}$ & $\begin{array}{l}\text { Geef een rapportcijfer voor de } \\
\text { hieronder genoemde aspecten van de } \\
\text { door u gevolgde HBO-opleiding. } \\
\text { "Samenhang tussen vakken" } \\
\text { Geef een afgerond cijfer tussen } 1 \text { en } \\
10 .\end{array}$ \\
\hline $\begin{array}{l}\text { Eindbeoordeling } \\
\text { programma }\end{array}$ & $\begin{array}{l}\text { Het gemiddelde van de } \\
\text { bovengenoemde } 3 \text { indicatoren voor } \\
\text { programma. }\end{array}$ & \\
\hline
\end{tabular}




\section{Berekening indicatoren voor oordeel personeel}

\begin{tabular}{|l|l|l|}
\hline Indicator & Berekeningswijze & Vragenlijst \\
\hline $\begin{array}{l}\text { Oordeel kwaliteit } \\
\text { van docenten }\end{array}$ & $\begin{array}{l}\text { Procentueel aandeel van de } \\
\text { afgestudeerden dat een rapportcijfer } \\
\text { van 6 of hoger toekent aan de kwaliteit } \\
\text { van docenten. } \\
\text { Dit percentage is als volgt omgezet in } \\
\text { een rapportcijfer: 10-(100- } \\
\text { Percentage)*4/25. }\end{array}$ & $\begin{array}{l}\text { Geef een rapportcijfer voor de } \\
\text { hieronder genoemde aspecten van de } \\
\text { door u gevolgde HBO-opleiding. } \\
\text { "Kwaliteit van docenten" } \\
\text { Geef een afgerond cijfer tussen 1 en } \\
10 .\end{array}$ \\
\hline $\begin{array}{l}\text { Oordeel } \\
\text { studiebegeleiding }\end{array}$ & $\begin{array}{l}\text { Procentueel aandeel van de } \\
\text { afgestudeerden dat een rapportcijfer } \\
\text { van 6 of hoger toekent aan de } \\
\text { studiebegeleiding. } \\
\text { Dit percentage is als volgt omgezet in } \\
\text { een rapportcijfer: 10-(100- } \\
\text { Percentage)*4/25. }\end{array}$ & $\begin{array}{l}\text { Geef een rapportcijfer voor de } \\
\text { hieronder genoemde aspecten van de } \\
\text { door u gevolgde HBO-opleiding. } \\
\text { "Studiebegeleiding" } \\
\text { Geef een afgerond cijfer tussen 1 en } \\
10 .\end{array}$ \\
\hline $\begin{array}{l}\text { Eindbeoordeling } \\
\text { personeel }\end{array}$ & $\begin{array}{l}\text { Het gemiddelde van de } \\
\text { bovengenoemde 2 indicatoren voor } \\
\text { personeel. }\end{array}$ & \\
\hline
\end{tabular}

\section{Berekening indicatoren voor oordeel voorzieningen}

\begin{tabular}{|c|c|c|}
\hline Indicator & Berekeningswijze & Vragenlijst \\
\hline $\begin{array}{l}\text { Oordeel } \\
\text { huisvesting }\end{array}$ & $\begin{array}{l}\text { Procentueel aandeel van de } \\
\text { afgestudeerden dat een rapportcijfer } \\
\text { van } 6 \text { of hoger toekent aan de kwaliteit } \\
\text { van de huisvesting. } \\
\text { Dit percentage is als volgt omgezet in } \\
\text { een rapportcijfer: } 10-(100- \\
\text { Percentage })^{\star} 4 / 25 \text {. }\end{array}$ & $\begin{array}{l}\text { Geef een rapportcijfer voor de } \\
\text { hieronder genoemde aspecten van de } \\
\text { door u gevolgde HBO-opleiding. } \\
\text { "Huisvesting" } \\
\text { Geef een afgerond cijfer tussen } 1 \text { en } \\
10 .\end{array}$ \\
\hline $\begin{array}{l}\text { Oordeel overige } \\
\text { materiële } \\
\text { voorzieningen }\end{array}$ & $\begin{array}{l}\text { Procentueel aandeel van de } \\
\text { afgestudeerden dat een rapportcijfer } \\
\text { van } 6 \text { of hoger toekent aan de overige } \\
\text { materiële voorzieningen. } \\
\text { Dit percentage is als volgt omgezet in } \\
\text { een rapportcijfer: } 10 \text {-(100- } \\
\text { Percentage })^{\star} 4 / 25 \text {. }\end{array}$ & $\begin{array}{l}\text { Geef een rapportcijfer voor de } \\
\text { hieronder genoemde aspecten van de } \\
\text { door u gevolgde HBO-opleiding. } \\
\text { "Overige materiële voorzieningen, } \\
\text { zoals bibliotheek, mediatheek, } \\
\text { werkplaatsen, ict-voorzieningen" } \\
\text { Geef een afgerond cijfer tussen } 1 \text { en } \\
10 .\end{array}$ \\
\hline $\begin{array}{l}\text { Eindbeoordeling } \\
\text { voorzieningen }\end{array}$ & $\begin{array}{l}\text { Het gemiddelde van de } \\
\text { bovengenoemde } 2 \text { indicatoren voor } \\
\text { voorzieningen. }\end{array}$ & \\
\hline
\end{tabular}

